\title{
SHAKESPEARE'S HISTORIOGRAPHY
}

by

\author{
Fobert Lesije Ewens
}

A thesis

submitted to the Victoria University of Welington in fulfilment of the requirements for the degree of Master of Arts

in English Literature

Victoria University of Wellington 1998 
To my perents, Jean and Terry 


\section{Abstract}

This study explores, in a sixteenth century context, the mistorical thought and consciousness of a selection of Shakespeare's English nistory plays. Looked at in relation to contemporary historiographical works, it is concluded that the plays in question qualify as a form of dramatic historiography both transitional and progressive in nature.

The studys after considering some aspects of Tudor historiography relevant to shakespeare and his drama in the introductory chapter, goes on in chapter one to explore Shakespeare"s Henry Wh sequence. My discussion finds that the interaction of the roles and requirements of both dramatist and mistorian has two important results: firstiy an emerging awareness of the impossibility of presenting the nistorical "truth": and secondly an appreciation that the (re)construction of a linear nistorical narrative (dramatisation); especially when developed from diverse Chronicle accounts, requires the dramatist/historian's critical and historical judgement concerning probability. Also observed in this chapter is the drama's capacity for making character as much a part of history as event.

In Chapter Two shakespeare's Fichard $2 T$ is juxtaposed with its main source, sir Thomas More's History or King Fichard TI. These texts provide a springboard for discussion of the tradition of oral history and the problems associated with its use as a souree for authoritative nistoriography, 
and the apparent resemblance between the historian's and lawyer's pursuit of the "truth" "The methods and principles of the courtroom are intimately related to those used by the dramatist/historian.

The final chapter couples the anonymous history play Edward III with Shakespeare's most sophisticated history. Henry " In this chapter I first discuss the growing sixteenth century distinction between poetry (the medium of the history play) and historiography. The history presented in Edward III is interrupted and dismupted by the "poetic" interlude of king Edward's residence at the countess of Salisbury seatleg I argue that the play (ironically, given its own status as verse drama) privileges "history" at the expense of "poetry" In Henry evidence of a conceptual shift in the use and perception of history" Here" also" is found the full realisation of the ineluctable evasiveness of historical "truth" through the contradictory accounts of the chorus and the stage action, and the opatity of king Henry. 


\section{Acknowledgements}

In the production of this thesis I am greatly indebted to my supervisor" Dr kim walker" for her invaluable ideas. suggestions, and overall guidance, and her willingness to undertake the unenviable task of reading and correcting my many drafts. 


\section{Contents}

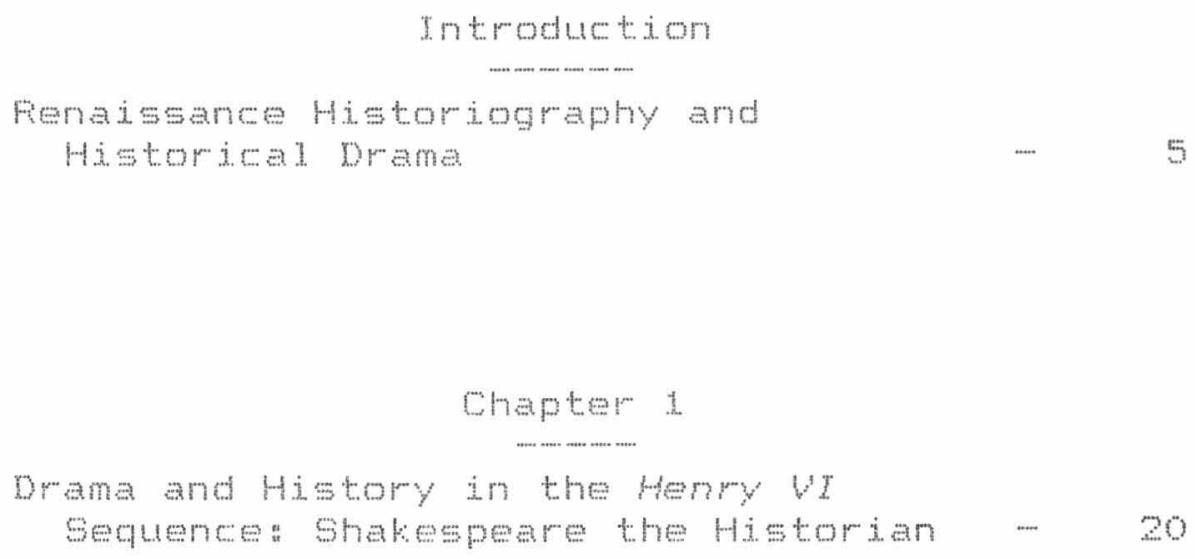

Chapter 1

Drame and History in the Henry WI

Sequence: Shakespeare the Historian - 20

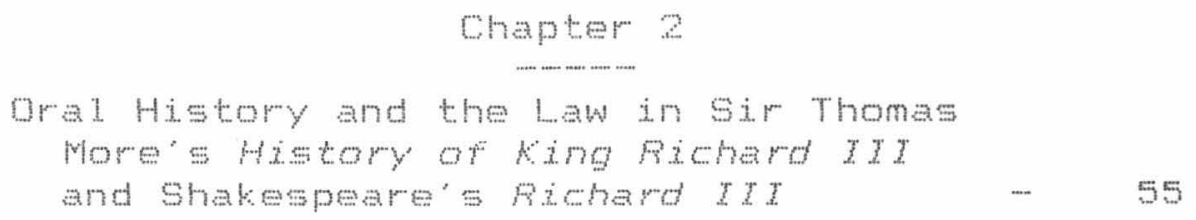

\section{Chapter}

Foetry and History in Edwerd TIT and Shakespeare's Henry 
Renaissance Historiography and Historical Drama

\section{History and Precedent}

Within sixteenth century Tudor society: history was predominantly prized for its capacity to instruct and educate. Humanists agreed that through the study of history one could learn how to act by observing the consequences of an action as it took place in the past. Fast failures could thus be avoided and past successes emulated.

It is this belief we find exemplified in sir Thomas Elyot's The Eook named the Gowernor. Here. Elyot emphasizes the educative value of history, especially as appertaining to the English governing class. To be truly fit and worthy of their high societal position, Elyot thought that the "Governors" should be well versed in a number of areas. including a knowledge of history and historical precedent, for:

there is no doctrine, be it either divine or human, that is not either all expressed in history or at the least mixed with history" "And then must history which cometh thereof be wonderful profitable, which leaveth nothing hid from man's knowledge, that unto him may be either pleasant or necessary. " Finally so large is the compass of that which is named history, that it comprehendeth 
all thing that is necessary to be put in memory.x

History, therefore, is to be read as an amalgam and 1. 1.ustration of "pleasant or neceseary" doctrine relevant to contemporary situations:

Wherefore Lactantius saith, "Thou must needs perish if thou know not what is to thy 1 ife profitable " that thou mayest seek for it, and what $i s$ dangerous, that thou mayest flee and eschew it.' Which I dare affirm may come soonest to pass by reading of histories, and retaining them in continual remembrance.

This last requirement of Elyot's, to retain history "in continue 1 remembrance", signifies one of the defining characteristics of sixteenth century historical thought and consciousness, that being the implicit belief in the continuity of history" It was this belief, which failed to recognise any differentiation, distance, or discontinuity between the past and the present, that was responsible for history's immediate availability and relevancy to current stuations and circumstances. However. at the same time as the past was being scoured for the purposes of present edification, a new awareness was gradually dawning, through

1. Sir Thomas Elyot, The Book named The Governor (1531). Ed. S.E. Lehmberg (London: Everyman's Library, J.M. Dent \& Sons Ltd, 1966), pg 230.

EIyot, pg 231.

"F. Smith Fussner" in his Tudor History and the Historians (New York: Basic Books, 1970), pg 258-259, states that "very few writers of the sixteenth century perceived that there could be serious problems of discontinuity." 
the discovery of more differences than similarities or parallels, of "the past as other - of societies with their own language, institutions, laws, and customs" "4 This discovery would, in time, lead to what kamps calls the "innovative" recognition that any examples extracted from the past were "inextricably linked to their unique historical context and could not be treated as if they were transhistorically applicable," thus indicating the eventual supercession of the continuous view of history for the discontinuous.

A further example of the Tudor approach to history comes from Richard Stanyhurst's "Preface" to the Irish history component of Holinshed's Chronicle (1577). Here, however", the emphasis is altered from Elyot's claim that "histories" may be personally "profitable" (though for "Governors") to the more overtly political concern of attaining or preserving the public good, or "wealpublicke"

And truely, to my thinking: such magistrates, as meane to haue a vigilant eye to their charge, can not bestow their tyme better" then when they sequestre themselues from the affayres of the wealpublicke, to recreate \& quicken their spirites by reading the chronicles, that decipher the gouernement of a wealepublicke. " And who so will be addicted to the reading of hystories, shall

4Ivo Kamps, Historiography and Ideology in Stuart Drama (Cambridge: Cambridge University Press, 1996), pg 37.

skamps; pg 45. 
readily finde diuerse euentes worthy to be remembred, and sundry sounde examples daily to be followed.s

Within stanyhurst's "hystories" are countless examples upon which "magistrates" should base the governing of "their charge" "His history - that of the "Chronicles" - thus becomes a repository of "woorthy" and "sounde" political precedent to be "remembered" and "followed" to the general berefit of the current "wealpublicke" "Once more in evidence is the implicit belief in the continuity of history, the unquestioned comparability and correspondence of the past to the present.

Tudor society thus held history in the highest esteem and viewed the study of history as an activity of immense personal and political benefit. An indication of this high esteem can be seen in the following panegyrit: from Stanyhurst"s "Preface"

Vpon which grounde the learned haue, not without cause, adiudged an hystorie to be the Marrowe of reason: the creame of experience " the sappe of wysedome, the pith of iudgement, the library of knowledge, the kerneli of pollicie, the vnfoldresse of treacherie, the kalender of tyme, the lanterne of trueth, the lyfe of memorie, the doctresse of behauiour" the register of antiquitien the

Gichard Stanyhurst, Holinshed's Irish Chronicle (1577 ed.), ed. Liam Miller and Eileen Power (Dolmen Editions. North America: Humanities Press Inc.: 1979), pg 9. 
These: then, were the inherent qualities history was thought to possess and consequently impart through study.

Elyot's, and to a lesser extent stanyhurst's: views of history (as eited above) can be seen to represent one of the two traditions" or "trends" "that Irving Fibner has isolated as being influential to Tudor historiography:

We cen thus isolate two distinct trends which exerted an influence upon Elizabethan historiography" a humanist trend essential1y classical in origin [Elyot, Stanyhursty, and a medieval trend based upon the premises of Christian belief.

It was the intermingling and interation of these and other less traditional modes of historiography (such as the antiquarian school), without any "clear distinction" or "apparent awareness of any inherent contradiction" $\Rightarrow$ that led" in Fibner's views to a historiography of "flux and uncertaintys with new and heretical notions competing in men's minds against old established ideas which could no longer be actepted without doubt and questioning."xo

\footnotetext{
7 stanyhurst. pg 9.

eIrving Ribner. The English History Play in the Age of shakespeare (London: Methuen \& Co, 1965), pg 21-22.

Fibner: pg 22,

1ofibmer, pg 10.
} 
This view of Elizabethan historiography is reflected and elaborated upon by both Graham Holderness and Ivo Kamps. Holderness, in his assessment of Elizabethan "culture" "and by implication historiography, states that:

Elizabethan culture was as diverse and as contradictory as could be expected of the culture of a rapidly changing and at times turbulent historical period.." [with] connected but separable and conflicting ideologies, dominant, residual and emergent. ${ }^{1 x}$

In a similar vein, though more directly in relation to sixteenth century historiography (rather than Holderness's "culture"), Kamps asserts that the differing "approaches to the past [identified as "providential, humanist, and antiquarian"] contradicted one another significantly, yet coexisted, 'progressing' and often intermingling in unpredictuble ways " 12

Holderness then proceeds, and is echoed by Kamps, to define and describe the influential "ideologies" of the humanist and medieval historians" The humanist historian was:

concerned with history as a source of moral instruction and political wisdom: with how a prince should ruleg how a people should conduct itself, in the light of an

\footnotetext{
1. Graham Holderness, Shakespeare Fecycled" The Making of Historical Drama (Hertfordshire: Harvester Wheatsheaf, 1992), pg 4-5.

xаkemps, pg 199.
} 
intelidgent and informed reading of history " ${ }^{2}=$

This is clearly in line with Elyot's intent that the English governing ciass improve their "rule" and "conduct" through an "intelligent and informed" study of history"

The medieval historian's ideology: which is inherited by and evident in "the encyclopedic chronicles of Halle and Holdinshed"x4 was, on the other hand"

dominated by the heritage of medieval christianitya a philosophical system in which the staten" "Was considered] as one of the functions of a universal order" created and supervised by God, and ruled directly by the machinations of divine providence. ${ }^{x}$

Both the humanist and medieval historian, while working from different ideologies, worked towards the same didactic end of appropriating history for present edification " Both" therefore: implicitly acknowledged the continuity of history which made their respective histories appropriable for such

x.Holderness, Shakespeare Recycled, pg 9. Kamps, pg 28, describes humanist historiography as using "texts of classical antiquity for exemplary instances by which to guide moral, literary" and political conduct in the present."

1. Holderness; Shakespeare Recyched, pg 5.

1.Holderness: Shakespeare Recyched; pq 2-3. Kamps, pg 28, aso describes medieval historiography as "concerned first and foremost with explicating the links between divine providence and human affairs " 


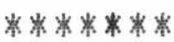

A dramatization of the Tudor use of, and attitude towards, history as precedent occurs in the anonymous English history play woodstock (c.1592), which covers the early years of king Fichard II's reign. The tension of the play revolves around Richard's abandonment of his uncles and their "wise" counsel in favour of his more youthful and flattering favourites:

Sir Edward Bagot, Bushy, Greene" and Scrope.

Your youths are fitting to our tender years

And shall beautify our princely throne.

Fear not my uncles nor their proudest strength

For I will buckler ye against them all."

$$
(I I, I, 3-7) x
$$

Later in this scene, one of Richard's favourites, Bushy, is seen reading a book and, when questioned what it is answersa

The monument of English Chronicles.

. ofegarding this point Holderness, in Shakespeare Recycled, po 9" states: "This concern with practical utility and contemporary relevance gave humanism common cause with medieval providentialism" both" being committed to learning from history, were forced to assume that past societies were essentially no different from the present."

1.7hat the Tudor approath to history, represented here in Fichard II's late-fourteenth century court, is somewhat anachronistic is noted but not our concern here.

1. Moodstock" A Moral History" ed. A "F" Fossiter (London" Chatto and Windus . 1946)" All. subsequent quotes are taken from this editionn 
Containing acts and memorable deeds

Of all your famous predecessor kings.

( I. . i. . 55-57)

From these "Chronicles" one can, according to Bushy, discover "Examples strange and wonderful" (1.59). The particular "example" that interests Bushy is one which bears direct relevance to their current situation, and can thus be used as a contemporary guide:

For here tis said your royal grandfather [Edward III]

Although but young, and under government,

Took the Frotector then, proud Mortimer"

And on a gallows fifty foot in height

He hung him for his pride and treachery"

$$
\text { (I.I. . . . 61-65) }
$$

The young king Edward's riddance of his Frotector Mortimer, then, stands as a historical precedent, due to the situational similarity or continuity of history, for the young king Fichard to "punish" his own Frotector (Woodstock) - a fact that Fichard keenly seizes upon:

Why then should our proud Protector then presume And we not punish him, whose treason's viler far Than ever was rebeli.ious Mortimer? " " examples such as these Wi.l. bring us to our kingly grandsire's spirit.

$$
\text { (II. i. } 66-70 \text { ) }
$$

Discussion then turns to Fichard's father" Prince Edward the Black Frince: and thereby illustrates another use of history 
- history as a source of inspiration for the present. Reading from his "Chronicle" Bushy recounts the Black Prince's victory, against all odds, over the French at Poitiers, a victory which momentarily inspires fichard:

But these bright shining trophies shall awake me. And as we are his body's counterfeit. So will we be the image of his mind, And die but we' 11 attain his virtuous deeds.

$$
\text { (II. . . . 92-95) }
$$

Expressed in these lines are the effect such heroic history should have on a hearer or reader" the Black Frince's successes "shall. awake" Fichard to perform the same. Richard also draws on the notion of the continuity of history through his assumption that his body is the "counterfeit" of his father, and that his "mind" can mirror ("image") the genealogical. precedent.

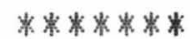

For the Tudor historian there was an established corpus of historical information which, having become accepted tradition, was considered as unchangeable, unchallengeable, and, to all intents and purposes, "true" "The authorial principles behind the composition or construction of Tudor historiography are succinctly captured in Paola fugliatti's statement that: "writing about history was considered a matter of re-writing and telling a matter of re-teling " $x$

4Fala Pugliatti. Shakespeare the Historian (London: Macmill an Press Ltd, 1996), pg 32. 
The historiographer's task was therefore viewed as one of compilation rather than "original" authorship" of re-working and re-wording what might already be common knowledge.

F. Smith Fussner defines this characteristic of Tudor historiography in terms of "adaptation" and "aceretion" "ao "adaptation" is associated with the imitation" borrowing or modification of one author's work by another" "accretion" is the accumulative collection and subsumption of material from author to author. Flagiarism was not an issue as the historian collected, compiled and conveyed his historical material for the edification of his audience.

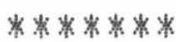

Further to the diverse and contradictory historiographical landscape, dominated by the humanists and medievalists (and discussed above), Holderness recognises a third emerging presence which, appearing in the "later sixteenth and early seventeenth centuries" he labels "new" or "modern" history. This form of history was not interested in "theological pattern, moral instruction or political wisdom" but in viewing the "past as fact" "Consequently, the "past" in question became "visible as nothing more or less than the history of man, a naturalistic rather than a providential process, and therefore subject to question and

sofussner, pg 239. 
rational analysis" "ax This "new" conception of history: therefores looks at the past's relation to the present as both differentiated and discontinuous.

History and Historical Drama

The genre of the English history play - which came to prominence in the 1580 s, reached its peak towards the end of the sixteenth century, and declined rapidly in the early seventeenth centuryaz -. can be seen as occupying a pivotal position in the development of historiography. The English history play receives the historical ideas and traditions of the medieval and humanist historians while also looking ahead to the jdeas of "new" or "modern" history"

The historical drama of the Fenaissance straddled a cultural transition in which more recognisably 'modern' ways of understanding the past were borna in fact the

zholderness. Shakespeare Recycied" pg 10. This "new" history described by Holderness shares points of resemblance with Kamp's definition, pg 28, of the antiquarians who "reconstruct through the study of both textual and physical remains " the past for its own sake." Elsewhere (pg 48), kamps is at pains to warn against seeing the "mareh" of historiography towards this "new" or "modern" conception as one of strict chronologically ordered progression, for "it would be to streamline retrospectively the truly erratic and varied history of historical scholarship." [to] present it as a teleological march toward a modern historiography."

maphylis Rackin. Stages of History Shakespeare's English Chronicles (New York: Cornell University Press, 1990): pg 31. kamps, pg 1, however, sets out to revise this preponderant cortical belief of the seventeenth century (Stuart) history play"s "inferior status [when] compared to Elizabethan history plays" by stating a case for "a new appreciation of the stuart historical drama's conceptual. historiographical. and aesthetic strengths " 
emergence of that new historiography coincided with the demise of the historical draman $a$

Holderness here seems to imply that the "historical drama" contributed to its own demise through the "new historiography" "s absorption and development of the drama's "understanding of the past" " Making this point more emphatically is kamps who" in his "Conclusion" "states that the genre of the history play met its demise "because the playwrights had taken the genre as far as it could go: they had first written historical plays and then written plays about the writing of history" "Therefore, "it is virtually certain that by becoming increasingly sophisticated in its representation of the nature of historical representation, the history play wrote itself out of existencen"a4. It must be remembered, however, that Kamps's primary focus is on Stuart historical drama " While he recognises that "Tudor drama oceasionally makes [historiographical] representation an issue" (he identifies Shakespeare's Henry $b$ as one such example), it is the "Stuart drama [that] is generally more dexiberate in its styling of historiographic representation." ": :

The transitional position of Fenaissance historical

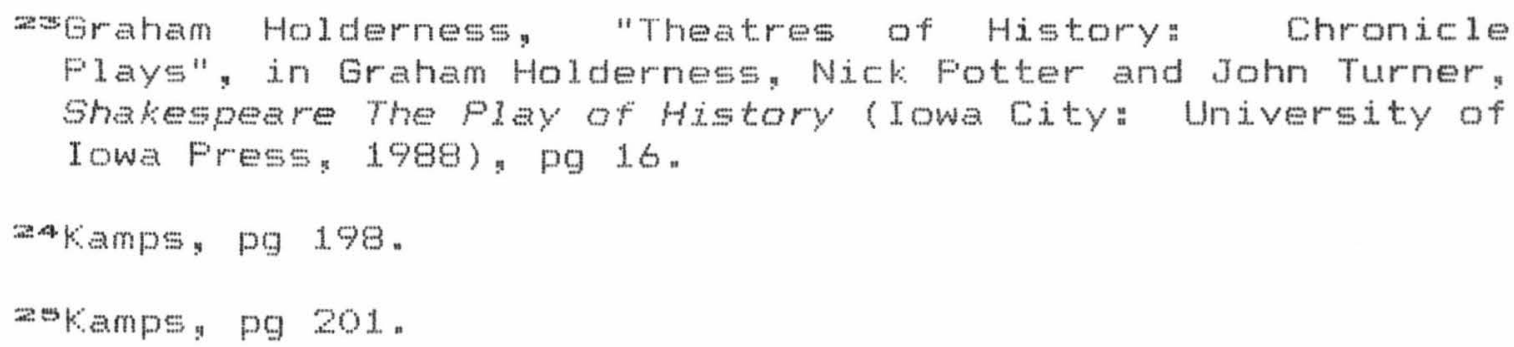


drama found by Holderness is also suggested by Fhyllis Fackin when, focusing specificaliy on Shakespeare's English history plays, she describes those plays as occupying:

various sites of contention [at the end of the sixteenth century] between older and newer conceptions of history and between the emergent distinctions that defined history and poetry in terms of mutual opposition. 20

Rackin believes that Shakespeare's plays, in order of composition from Henry $v$ to Henry $w$ indicate the progress of late sixteenth century historiography in two ways " firstly by their "increasing sense of alienation from the past, of i.ts [the past's] ineluctable otherness": and secondly by their (self-reflexive) portrayal of the problems of discovering "historical fact" and representing "historical truth":

Historical fact was now open to question, and historical truth was now debatable. Fecords were subject to loss or distortion, witnesses could be biased, and all things were vulnerable to the ravages of time nat

Such a new scepticism was, of course, a direct consequence of the "increasing sense of alienation" from the past wherein nistory came to be seen as comprising numerous specific and "past" moments, distant from the "present", and with their own unique questions and problems.

\footnotetext{
moRackin, PG 21. The "emergent distinctions" between history and poetry are discussed in this essay in Chapter 3

arRackin, pg 12.
} 
This emerging perception of the discontinuity of history eventually leads to what Fackin identifies as "the abyss at the center of the historiographic project" "ze Here is the realisation that the "truth" is distant and irrecoverable, and thus impervious to "true" reconstruction - a state of affairs which the plays steadily point us towards"

The chapters that follow explore a selection of Shakespeare's English history plays in the context of Holderness"s assertion that these plays are "in themselves and not derivatively [ie. due to their sources], historiography" " that they are:

not just reflections of a cultural debatea they are interventions in that debate, contributions to the historiographical effort [of the late sixteenth century] to reconstruct the past and discover the methods and principles of that reconstruction. 29

I consider their historical thought and consciousness in relation to each other and/or associated texts approach to the problem of establishing or representing "historical truth" and their awareness of the historical and historiographical processes of which they are a product. Overall it will be seen that the plays as Fackin argues, increasingly counteract the very process they purport to undertake - the (re)presentation of "historical truth" "

\footnotetext{
zarakin. pg 69. We return to this historiographic "abyss" as a point of resolution, at the close of chapter 3 .

"araham Holderness, Shakespeare Recycied, pg 13.
} 


\title{
Chapter 1 \\ Drama and History in the Henry VI Sequence: Shakespeare the Historian
}

Shakespeare's three Henry ut plays occupy a crucial position within the English history play genre for two reasons: firstly they stand as Shakespeare's initial contributions to the genre, and secondly their early $1590^{\prime} \mathrm{s}$ composition and debut performance dates place them at the beginning of the decade or so in which the English history play reached its peak of popularity. Regarding these plays Irving Fibner states:

\begin{abstract}
The Henry WI plays are more rich and varied as drama and as poetry than any history plays written before them, and they mark an advance in the evolution of the genre by the seriousness with which shakespeare approached the task of the historian. ${ }^{2}$
\end{abstract}

The issue I will discuss in this chapter is how the dual roles of Shakespeare as playwright and shakespeare as "historian" interact to produce a dramatic historiography which is progressive in terms of contemporary (1ate sixteenth century) historical thought and consciousness" More specifically, how shakespeare the "historian"'s perception of any limitations or inadequacies in his contemporary historiography (especially that being used as a source) inhibits and/or conflicts with the requirements placed upon him by the dramatic medium, and how these "problems" are

\footnotetext{
ribner; pg 101.
} 
addressed dramatically in such a way as to mark an advance in the aforesaid historical thought and consciousness.

My discussion makes use of four separate" though not necessarily mutually exclusive, aspects of the texts. These are:

i.) The texts" attitude towards" and treatment of, their sources -- namely the Chronicles of Hall and Holinshed.

i.) Theit explanation of the causality of eventa as opposed to that expressed in the sources.

i.i.) The uses the charatere make of history within the environment of the play.

iv) The contribution of the dramatic mode of presentation to the treatment of history and historical $\operatorname{mater} i \operatorname{li}$

The Treatment of Sources

The murder of the Duke of Gloucester in 2 Henry $V T$ (III.i.) and the Countess of Auvergne - Lord Talbot encounter in 1 Henry VI (II i.i. are two episodes from the Henry VI sequence which occupy completely different positions in relation to the Chronicles: positions which consequently allow each to comment, in its own specific way, on some perteived shortfall of those sources. The Duke of Gloucester episode, which is derived from the chronicles, uses this position to react against their historiographical methods, while the Countess of Auvergne - Lord Talbot encounter uses its position as invented, and thus not derived from the 
Chronicles, to objectively question the same "Both, in their respective reation and invention, can be seen as evincing an active rather than passive historiography.

The murder of Duke Humphrey of Gloucester in Act III

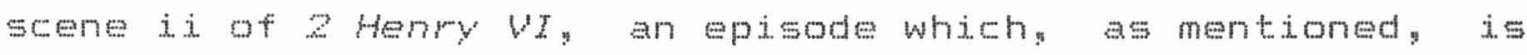
grounded in the chronicles" provides an illustration of Shakespeare's texts interacting with and reacting to their soureses in the manner of a "serious historian" "The Duke of Gloucester is king Henry's uncle and (acting as) Lord Frotector while Henry is in his nonage. In the scene preceding the murder, a group of Gloucester's sworn enemies Suftolks Queen Margaret, Cardinal Beaufort, and York discuss the arrangements for the impending deed. Dstensibly their motive is to guard king Henry from Gloucester's evi1intentioned influence and ambition. The king is thus, to their mind" in need of protection from his Frotector"

York Were't not all one, an empty eagle were set To guard the enicken from a hungry kite. As place Duke Humphrey for the king's Protector? Queen Margaret" so the poor ehicken should be sure of death.

(III. I. $248-251)=$

The metaphors are revealing herey for while Vork represents Gloucester as an "empty [hungry] eagle" "the equally hungry

william Shakespeare: The Second Part of king Henry the Sixth, ed. Norman Sanders (London: Fenguin Books Lted. 1981) "Al. subsequent quotes are taken from this edition. 
"kite" may be interpreted as the schemers themselves. Whatever the case, their intent is clearly gratuitous. Agreement is eventually reached by the conspirators, and voiced by suffolk, that:

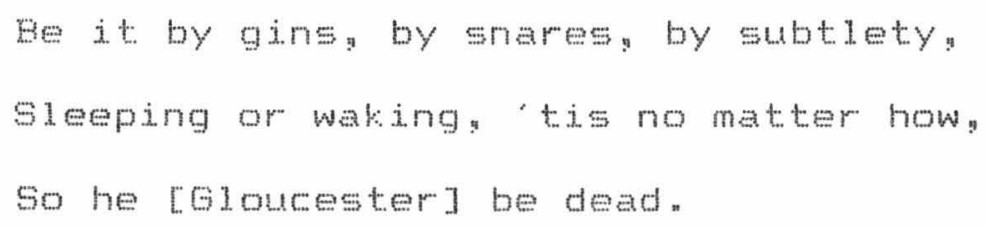

The Cardinal accepts this, and articulates his desire for haste:

But I would have him dead, my lord of Suffolk,

Ere you can take due order's for a priest.

$$
\text { (III. i. } 273-274 \text { ) }
$$

The murder of Gloucester is therefore imminent, and it comes as no surprise to see, in the next scene" two Murderers reporting to suffolk:

Suffolk: Now, sirs, have you dispatched this thing? Eirst Murderer: Ay, my good lord, he's dead.

$$
\text { (III. i.i. } 6-7 \text { ) }
$$

Suffolk's interview with the two Murderers suggests a possible cause of death - esphyxiation while sleeping - when he enquires of them" "Have you laid fair the bed?" (1.11). This suggestion is confirmed later by warwick in his description and analysis of bloucester's corpse, and his deduction of a "probable" cause of death: 


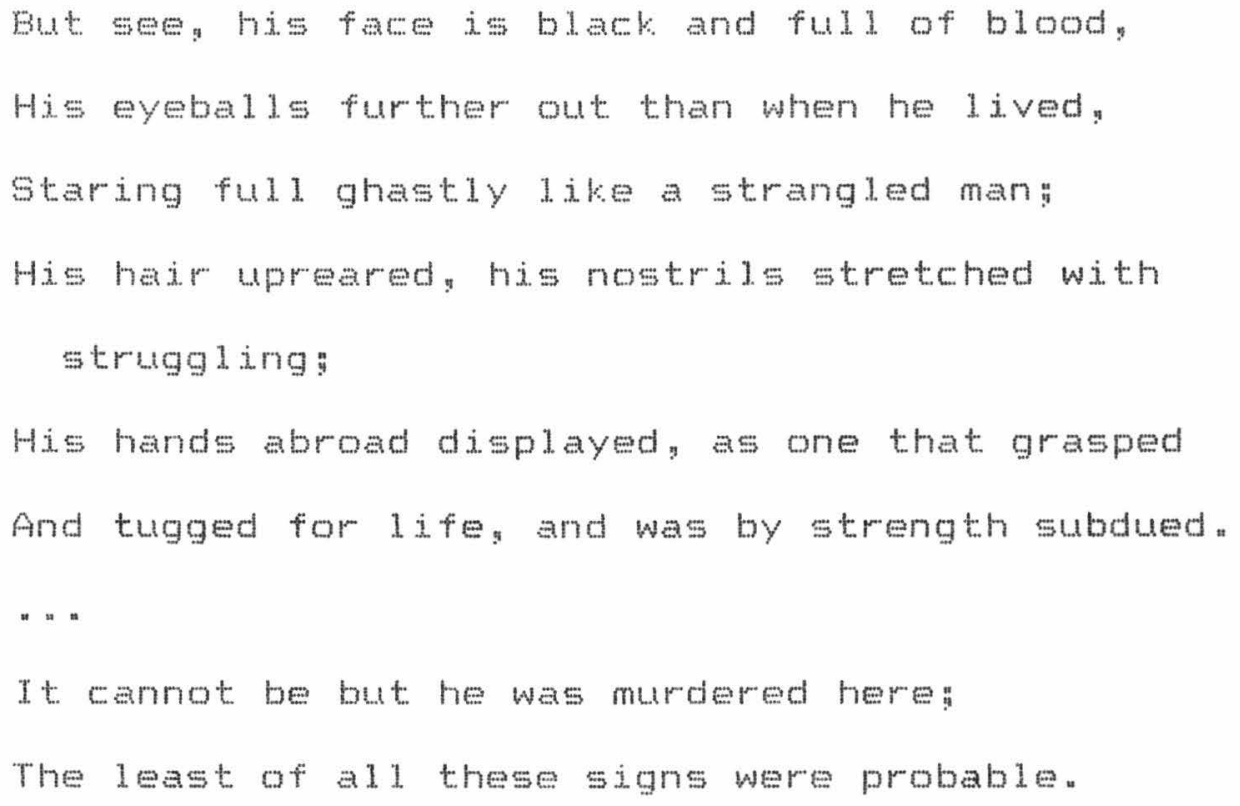

The duke [of Gloucester]" " "Was found dead in his bed, and his bodie shewed to the lords and commons as though he had died of a palsie, or of an imposteme.

Eut all indifferent persons (as saith Hall) might well vnderstand that he died of some violent death. Some iudged him to be strengled, some affirme that an hot spit was put in at his fundament, other write that he was smouldered betweene two featherbeds; and some haue affirmed that he died of verie greefe. for that he might not come openlie to his answer li. "y answer actusations 
made against himi.:

The overall effect here is inconclusive and indecisive - we have one chronicler (Holinshed) repeating another chronicler's (Hall's) list of possible verdicts sourced from what may well amount to nothing more than hearsay, popular speculation, or rumour " 4

Shakespeare, of course, cannot dramatise all of these possible causes of death, but for dranatic impact and the requirements of narrative continuity some explanation as regards Gloucester's death is necessary. It is through the fulfilment of such necessities that I think the plays (and thus the dramatist) exhibit the method and approach of a "serious historian" by asserting and applying their own critical and historical judgement. In this particular situation we see Shakespeare, as "historian" "constructing and portraying the most likely (Warwick's "probable") scenario given the information (characters " motives etc.") available. The scene thus replaces the passivity of Holinshed in cumulatively accepting and re-telling any relevant details with an active method of historical reconstruction, producing a researched historical hypothesis. Holinshed and Hall merely

\footnotetext{
*Allardyee Nicoll \& Josephine Nicoll (eds")" Holinshed's chronicle [2nd edition, 1587 ] as used in shakespeare's Plays (London" J.M. Dent \& Sons Ltd, 1927), pg 112-113. Al1 subsequent quotes in this chapter are taken from this edition.

4Fossibly the type of rumour described in the "Induction" to 2 Henry IV" "Fumour is a pipe / Blown by surmises, jealousies, conjectures" (Induction, 1.20). William Shakespeare, The second Part of King Henry the Fourth, ed. P.H. Davison (London: Fenguin Books Ltd: 1977).
} 
te11 us Gloucester was found deady and that there was speculation he "died of some violent death" "In 2 Henry WI this is converted into a hypothetical probability -... given the evidence this is what most likely happened "s shakespeare's historical approach, therefores seems to adhere to similar practical and pragmatic principles of judgement as those exemplified by his character warwick:

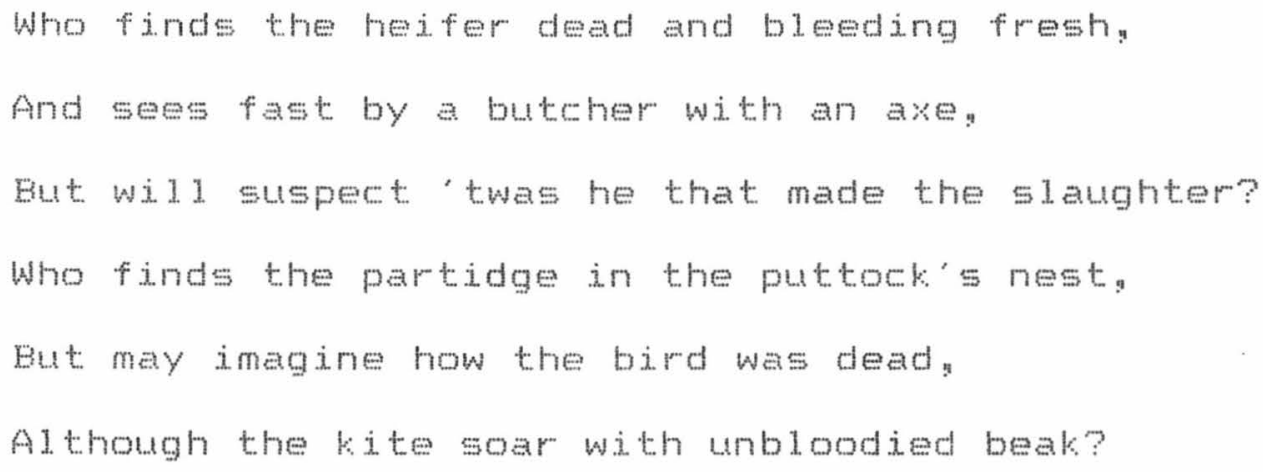

$$
\text { (III, i.j. 188-19\%) }
$$

Through the application of these principles, and driven (guided) by the necessities of dramatic production, shakespeare the "historian" can unify the cumulative and eclectic approach of Holinshed into a single, linear (rather than divergent) historical narrative. The resulting effect is one of authority - over both his source and its historiography - - as a more comvineing situation is reconstructed on stege from the inclusive 1.st of popular speculations found the chronicle "A convincing account may consequentiy be seen by an audienee as more closely approximating or resembling the "truth" "merely through its perceived authority"

"This aspect of historical (re)construction looks ahead to my discussion of eireumstantial evidenee on pp $73-74$. 
Thus, if shakespeare saw the "task of the historian" as that of (re)constructing a coherent and congruent historical narative from the received traditions of his sources (here primarily Hall and Holinshed)" then the dramatic medium lent him an amount of freedom, (poetic) 1icence, and discretion to do 5

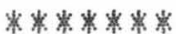

In the Countess of Auvergne -... Lord Talbot encounter (Act I scene i.i. of 1 Henry by), which, unlike oloucester's murder, has no besis in the Chroniclesy it seems shakespeare is acknowledging and dramatising a pereeived limitation of his sources (in general) and the processes of historical recreation on which they are built $\Leftrightarrow$ Throughout this dramatic, rather than historical, exchange we are repeatedly made aware of the intrinsic difficulty justifying popular perception or expectation ("report") with physical reality ("truth"), and the created image ("shadow") with the actual image ("substanee").

In order that the Countess may meet the man of whom she has heard 50 much rat this point we know nothing of her sinister intentions) an invitation is sent to Talbot. entreating him:

ofhyllis Rackin, in her discussion of this episode (pp 152155), makes some similar points to those made here y but sees the encounter as symptomatic of the play's overall portrayal of the French female characters (Joan la Fucelle, the Countess of Auvergne, and Margaret of Anjou) as "threats to the English protagonists and to the heroic values associated with history as the preserver of masculine fame and glory" "pg 152 . 
To visit her poor castle where she lies,

That she may boast she hath beheld the man

Whose glory fills the world with loud report.

$$
\text { (II. i.j. } 41-43)>
$$

The dichotomy being set up here for exposition, and possible resolution when they meet, is that between "the man" himself, Lord Talbot. and his "glory" "signified in "loud report" "The "glory" the Countess has in mind may derive from that which Shakespeare would have found in Holinshed's "loud report" of Talbot in France:

Lord Talbot, being both of noble birth, and of haultie courage, after his comming into France, obteined so manie glorious victories of his enimies, that his onelie name was \& yet is dreadful to the French nation: and much renowmed amongst all other people.

It is the Countess's stated intention to quantify this "glory" by meeting "the man" himself. As regards the Chronicle's ascription of "manie glorious victories" to the symbolic and nominal figure of "Lord Talbot". the encounter soon to take place will show that this falls a long way short of describing the actual and original (i.e." the "true") historical events and circumstances it suggests " To this extent: the countess - Talbot scene, which is fictional and of no historical consequence, can be seen as implicitiy and

\footnotetext{
TWilliam Shakespeare, The First Part of King Henry the Sxxth, ed. Norman Sanders (Londona Fenguin Books Ltd, 1981) "Al1 subsequent quotes are taken from this edition.

"Holinshed, ed. Nicoll, pg 98.
} 
self reflexively commenting on two jssues. Firstiy the problems facing any artistic (re)construction of an historical event or person in relation to (re)presenting the "truth", and secondly the narrow" "aristocratic", historical focus of the Chronicles.

Early in the scene of their meeting the Countess, alone for a moment, and in terms comparable to her invitation, again expresses the desire to prove by sight those "reports" she has heard:

Fain would mine eyes be witness with mine ears? To give their censure of these rare reports.

$$
\text { (I. I. i. }=9-10)
$$

Both the Countess's earider invitation and the aboves more personal, declaration, then, suggest the idea that seeing is believing: that only the eyes are a suitable locus of judgement through which to evaluate the accuracy of "report" " However" as the originating moment of a "report" has passed (which necessitates it becoming "report"), to establish the "truth" of a "report" through "beholding" or" "witnessing" is consequently impossible. Therefore" by definition" "report" can only resemble or represent, as a derivative of its moment of origin" the "truth" "This realisation" it follows "has repercussions for the entire historiographic process, for how else can history be recorded and transmitted but by "report" even though "report" is acknowledged as not "true"? It is this self-defeating and counter-productive acknowledgement of the nature of historiography's essential "untruthfulness" 
that the text seems here, in miniature" to be coming to terms with.

Once Talbot is admitted to the Countess's presence she is " of course. greatly disappointed" "What? Is this the man?" (II.jix.13)" Expecting "some Hercules: / A second Hector" (11.18-19), she finds the actuality quite bathetic: "a child, a sily dwart / It cannot be this weak and writhled shrimp" (11.21-22)" The pivotal line" which emphasises the point I feel the scene is making, is the countess"3 "I see report is fabulous and false" (1.17): what the Countess has heard by "report" (1.7) bears no resemblance to the "truth" before her". The credibility of historiography as "the lanterne of trueth" is thus put in question as Talbot's "report" and the Charater Tabot's visual reality, whith here signifies the "truth" are juxtaposed and shown to be incommensurable.

From line 3 of the Countess -.. Talbot encounter. the text turns from the questioning of "report" to a comparison of "shadow" and "substance" and the doubtful possibility of capturing either - be it in life or in the work of art or historiography . xo

In making a captive of Talbot: the Countess believes she now has possession of both his "shadow", in the form of a

\footnotetext{
stanyhurst.pg9.

1oIn the Fenguin edition of 1 Herry Wy po 185, "shadow" is defined as "images portrat". and "substance" as the "actual person" "
} 
portrait hanging in her" gallery" and his "gubstance" in the form of his person:

Lomg time thy shadow hath been thrall to me: For in my gallery thy picture hangs;

But now the substance shall endure the like "

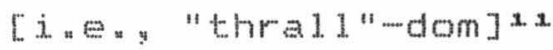

( I. . i.i. , $5-37$ )

Talbot: however" merely laughs at the Countess's naivety in thinking that what she has captured is any more than the "shadow" she already possessed" "I laugh to see your ladyship 5o fond / To think that you have aught but Talbot's shadow" (11. 44-45), Even as he stands before her" the character Talbot is "but shadow of myself" (1.49) - a replica, an actor playing the part of the "true" Lord Talbot. Therefore, as far as his physical presence on stage is concernedy the apparent differenee between his "picture" ("shadow") and "the man" ("gubstance") is imaginary" Each is an image or imitation or the "original" and historical Talbot in his "original" and historical context. As Talbot explains to the countess"

" My substance is not here:

x. My sense of what the Countess indicates by "the like" is at odds with Michael Hattaway who in his edition of The First Part of King Henry Yr (Cambridge: Cambridge University Fress: 1990)" po 105. annotates it as indicating "being hanged": obviously in reference to the previous line"s "thy picture hangs" I think. however. that the Countess is referring to what "thy shadow hath been" that is " a "thrall to me" "Despite her earlier stated intention to be "as famous" " by this exploit / As Stythian Tomyris by cyrus" death" (11.5-6). it is not Elear that the Countess intends to emulate the deed itself or merely to emulate the fame earned through that deed. Moreover, she goes on to speak not of hanging but of chaining Tabot"s "1egs and arms" (1.38)" 
For what you see is but the mallest part

And least proportion of humanity"

I tell you, madam, were the whole frame here,

It is of such a spacious lofty pitch

Your roof were not sufficient to contain't.

$$
\text { (II. I.i. } 50-55)
$$

A closer representation - and thus still effectively "shadow" - of his "substanee" is ganed when his soldiers enter the roon" "These are his substance. simews, arms, and strength" (1.62)" but, as he suggests above" the complete "gubstance" or "whole frame" is uncontainable and unrepresentable In this dramatic moment, theng with Talbot and his soldiers being described as "his substance" " the text is undermining the narrow focus of the chronicle in its ascription of "manie glorious victories" to "Lord Talbot" alone. By himself. the play here makes clear. Talbot is "but the smallest part / And least proportion" of the "whole frame"

In summary, the Countess of Auvergne - Lord Talbot episode can be read (or seen) as an implicit comment on the historiographic process as a whole through its awareness that in any work of historiography (including a historical play) which recollects and represents the past, neither the "whole frame" the whole "substance" "ror the whole "truth" can be portrayed. The reader or viewer must be aware of the paradox" "He will be here, and yet is not here" (1.57). Historical. characters such as Tabot, in the Chronicles as in 1 Henry V. are but the "shadow" of the "substance" - in the Chronicles they are a narrative conetruction ("report") " on 
stage they are a dramaturgical construction ("shadow") " The original "truth" ("substance") is, by definition, lost in any work of artifice, be it pictorial, textual, or dramatic.

The Exploration of Causality

We have already seen shakespeare at work on the causality of events in the scenes depicting the murder of the Duke of Gloucester" The exploration of causality of event performed elsewhere in the Henry WI texts repeats the "active" method of historical reconstruction found in the aforementioned situation. This is particularly evident in the way causality is secularized from the supernatural to the temporal, and the finer gradation of causes into primary (initial or original) and secondary (subsequent or derivative). Both of these are characteristic of the general move within the Fenaissance towards a more human-orientated focus, and a desire to question and explore received traditions and notions.

Warwick's description of the (second) battle at Saint Albans in 3 Henry VT (II.i.104-140), which supplies reasons for his side's defeat, is one example of the secularizing of cause. To make this clear it is necessary to compare the relevant passages from the play and the Chronicles this time Hall's The Union of the Two Noble and lllustre Famelies of Lancastre and Yorke (1548). Hall reports that Warwick's side. "havyng the kyng in their company, as the head and chefetayn of the warre" " met in battle the "Quene. "with her Northren 
people" at Saint Albans and were defeated:

Fortune that day so favored the Quene, that her parte prevayled, and the duke [of Norfolk] and the erle [ot Warwick] were djscomfited, and fled[. $]^{x}=$

The point of importance here is the reason for, or cause of, defeat that Hall provides" "Fortune"

In the play. however, warwick's version of the battle and the defeat is a litte more probing in nature:

Our battles joined, and both sides fiercely fought:

But whether 'twas the coldness of the king:

Who looked full gently on his warlike Queen:

That robbed my soldiers of their heated spleen:

Or whether' twas report of her sucesss

Or more than common fear of cijford's rigour.

Who thunders to his captives blood and death

I cannot judge" but " to conclude with truth,

a

they [Warwick's soldiers] had no heart to fight,

And we in them no mope to win the day:

So that we fled.

$$
\text { (II.i.120-127" "154-136)x: }
$$

xaEdward Hall, The Union of the Two Noble and Tlustre Fmelies of Lancestre and Yorke (1548), cited in Geoffrey Bullough (ed.)" Narrative and Drametic Sources of Shakespere: 6 vols. (London" Foutledge and Kegan Faul. 1960), VOI. "III: pg 179.

13 willam Shakespeare: The Third Part of king Henry the sxit. ed. Norman Sanders (London" Fenguin Eooks Lte. 1981). A11 subsequent quotes are taken from this edition. 
Heren a (secular) cause of defeat is searehed for in the events and circumstances peripheral to, and bearing upon, the bettle - the presence of the king: or fear of clifford, for example -- rather than the inscrutable "Fortune" with its medieval connotations of mutability" "Thanked be Fortune and hime false whee 1, / That noon estad assureth to be wee1."1.4

This seme, then, bears an interesting relationship to the previously discussed "murder of Gloucester" scene through the different manipulations of causality that are at work. In the oloueseter sene of 2 Henry ly the highly speculative and mulifarious account in Holinshed's chronicle is forged into the dramatic scenario of suffolk hiring two murderers to strangle Gloucester" in his bed. Conversely" Warwick's report of the Battle of saint Albans in 3 Herry w speculates on the causes of defeat whereas Hall simply attributes the cause to "Fortune" It would therefore seem that the attribution of cause to "Fortune" (Ha11) is as problematic and inadequate for the dramatist as the gathering of conflicting hearsay surrounding the cause of Gloucester's death (Holinshed). In both circumstances a Chronicle reader is no closer to the "truth" - they know oloueseter died but not how they know Warwick's army was defeated but not why.

The plays, however. by taking account of the context and surrounding variables of a situation or event -

\footnotetext{
146eoffrey Chaucer" "The knight's Tale". 11.925-926. in The Riverside Cheucer" ed. Larry D. Benson (Oxforda Oxford University Fress: 1992).
} 
personalities, motives, or social climate for example construct a human-orientated and human-motivated version of that situation or event. Fear in one's soldiers or lack of inspiration from the king: for exampley are more credible as causes of defeat than the intangible workings of Fortune. of course Warwick's report is by no means definitive - his withholding of judgement ("I cannot judge") is in the end as inconclusive as Hal1's "Fortune" "The difference 1ies in Warwick's use of viable circumstantial evidence around which he can speculate a cause of defeat. Hall merely recounts the event as a necessary link in his narrative chain. Searching for causes is not considered important at this point "Forture" will suffice"

Warwick's report also points towards the likelinood of multiple causes behind an event, and as a consequence suggests the absolute inability of either himself or the historian ever knowing the "truth" categorically. As Paola Pugliatti states"

Where in Holinshed indecision signals eclecticism in information ${ }^{2}$ athering, in shakespeare it assumes the form of problematisation, it becomes polyvalence. s.

The "indecision" in Holinshed regarding Gloucester"s death, then, is "eclectic" in that not all of the suggestions are simultaneously plausible or possible - the choice of one would rule out the others, indicating their inclusion as

\footnotetext{
x swoliatti. pg 49 .
} 
(Shakespeare's) report, however.

a.1. the suggested reasons for their defeat are simultaneously plausible or possible. This seems to evince in the dramatist, and provoke in the reader (or audience), an awareness of the problematic nature of historical knowledge" can one ever" know the "true" cause of: or underlying reason for, an event. Even Warwick, as an eye-witness, "cannot judge": he can only surmise ("whether "twas") by working backwards from the fact of defeat.

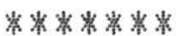

The best example of the gradation of cause into primary and secondary is that related to the causation of what is popularly termed the "Wars of the Foses". The Henry W plays appear to put forward the theory that the primary cause of the "Wars" is not the division and dissension between the factions of York (White rose) and Lancaster (red rose), but the weak kingship of Henry VI. It is Henry's lack of authority that makes possible the situation which escalates into the internecine feud between the Houses of York and Lancaster" This feud" therefore, becomes the secondary cause of the "Wars": subsequent and consequent to the primary cause "As the wounded clifford states in 3 Henry VI"

And: Henry [VI] hadst thou swayed as kings should do. or as thy father [HV] and his father [HIV] did, Giving no ground unto the house of York: They never then had sprung like summer fides:

I and ten thousand in this luckless realm Had left no mourning widows for our death: 
And thou this day hadst kept thy chair in peace.

For what doth cherish weeds but gentle air?

And what makes robbers bold but too much lenity?

$$
\text { ( I. . vi.14-22, my emphasis) }
$$

This attribution of primary cause to the weakness of Henry VI, and secondary cause to the York - Lancaster conflict, also questions the providential scheme of history dominant in medieval times; and largely inherited by the Chroniclers of the Tudor age, in which the governing force

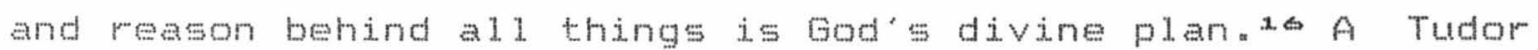
adjunct to this providential scheme of history was the theory, constructed by the very dynasty it explicitiy supports, of the "Tudor Myth" -. "that God had led England through the troubled times of dissension between Lancaster and Yorkist dynasties to fulfil her destiny with the enthronement of Henry Tudor as Henry VII."1. Under this theory, all history post-Fichard II is consequently seen as a preparation for the glorious Tudor dynasty.

Both the providential scheme of history and its ancil lary" the "Tudor Myth" theory, however", are not shown to be the driving forces behind the action in the Henry vI sequence. They are both acknowledged" but responsibility is seen to rest firmly within the human (temporal, secular) rather than the divine realm. As Michael Hattaway states:

1. See pg 11 for further discussion of this outlook.

x.Michael Hattaway, The second part of king Henry VT (Cambridge: Cambridge University Fress, 1991); pg 1. 
Shakespeare's reading of the troublesome reign of Henry VI, accordingly: takes its nature not from the visitation of divine vengeance for an original sin (the deposition and murder of Fichard II) committed two generations before but from the aspirations of particular estates.

It is pertinent to this point that the one character who does see God as the prime mover of all things, Henry VI himself -"To see how God in al1 his creatures works!" (2 Henry VI, I. I.7) - is shown as the least successful and the most desperately incongruous figure in the plays context of Machiavellian, Self-orientated, power politics. Henry, in keeping with his providential beliefy is also the one character" who draws explicit attention to the "Tudor Myth" " He does this in an address to young Henry, Earl of Richmond:

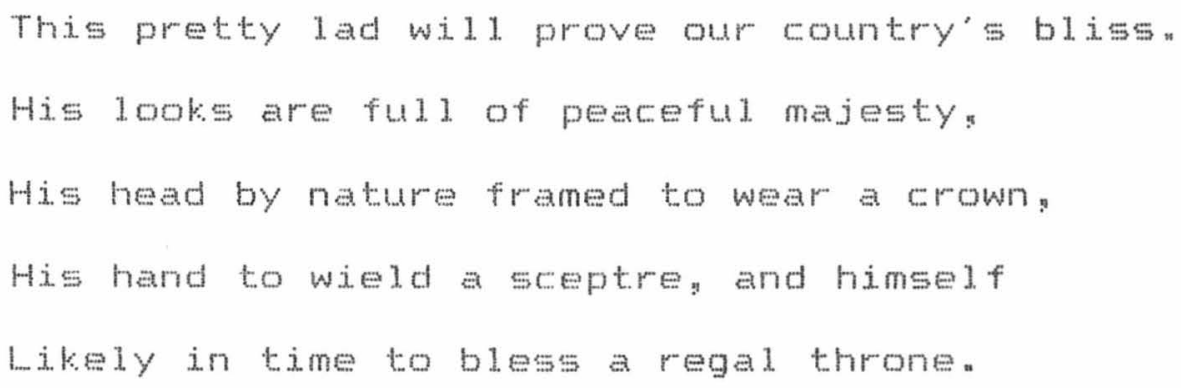

$(3$ Henry V., IV.

Outside of the plays dramatic environment and in that of Shakespeare's sixteenth century audience, this speech serves two purposes. Fichmond; in hindsight and commensurate with contemporary Tudor ideology: was indeed to prove his "country" $\Xi$ bliss" through his founding of the Tudor dynasty.

\footnotetext{
x. Hattaway, The Second Part of King Henry WI. pg 8.
} 
from which the current monarch, Queen Elizabeth I, is descended. Therefore, to pay lip-service to the "Tudor Myth" is here both politically and personally prudent. on the other hand, however, the inadequacy and powerlessness of the character Henry VI, and his (blind) faith in providence to resolve the tumultuous state of affairs around him - even though, in the case of Richmond, he was "right" - also works to undermine the very world-view this speech exemplifies, and the ideology it suggests. Shakespeare thus seems to be using his historiography for discreet contemporary comment.

The Use of History

A common usage of history by characters early in the Henry bT sequence is as a yardstick, gauge, or guide for present behaviour" In these situations history becomes something to either be inspired by, live up to, or follow. As an example we can use the historical (to the characters in the plays) traditions of knighthood, in particular the order of the Garter, and chivalry, the knight's code of conduct. ch $^{2}$ In 1 Henry VI it is the "old guard" of Lord Talbot and Lord Bedford who are portrayed as the paradigms of this knightly

x The Order of the Garter" founded by king Edward III in 1.348, was the highest of the English orders of chivalry and knighthood. The emblem of the order was a blue and gold garter worn buckled below the left knee by knights" their motto was "Honi soit qui mal y pense" (Fr. "evil to him who thinks it evil"). The chivalric virtues and qualities that knights were expected to exemplify included honour" piety" love courage" faith" and devotion. See entries under" "chivalry" and "order of the Garter" in Bradford B. Broughton, Dictionary of Wedieval Knighthood and Chivalry (Westport, Connecticuta Greenwood Press. $1986)$ 
and chivalmic tradition and thus as living up to the relevant examples of history for" "present" benefit. The antithesis is Sir Jonn Falstaff who, in deserting batte - "To save myself

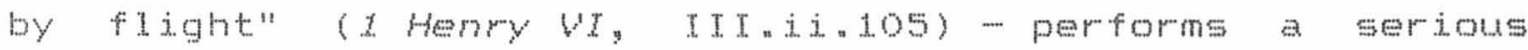
transgression. This crime of desertion is committed not only against his fellow soldiers but also, as Talbot himself makes Clear: against the knightly (historical) traditions themselves, specifically those of the knights of the Garter"

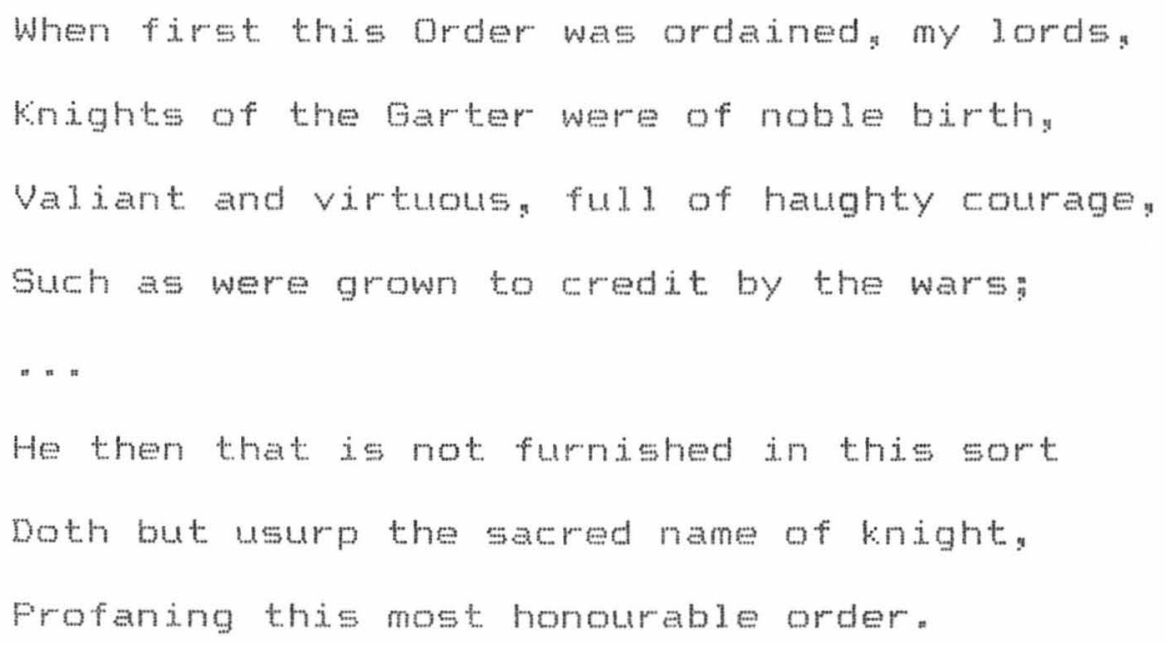

The sort of behaviour Falstaff should have exhibitedy in contrast to his desertion, is that of the Duke of Bedford who: though mortally wounded, will emulate the historical example of "stout Pendragon" and fight till the last"

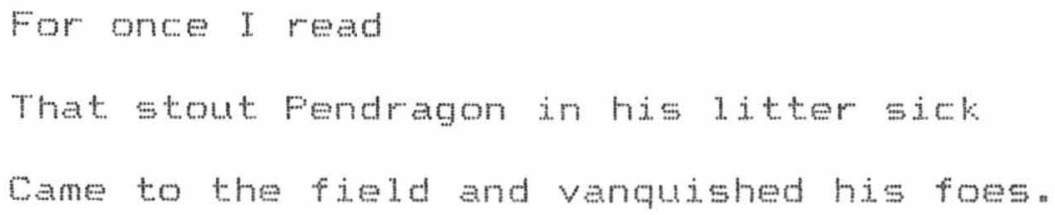

$$
\text { ( III. i. . 94--96) }
$$

Through this use of historical precedent, Bedford also hopes to have the same effect on his soldiers that history" in the 
form of the historiography of fendragon, has had on him: "Methinks I should revive the soldiers" hearts, / Because I ever found them as myself" (11.97-98). That is, he hopes to inspire and incite them to perform such legendary deeds as are found in history, be they Pendragon's or Bedford's. It is significant here that Bedford mentions his reading of history. In so doing, the text seems to be displayingy anachronistically: the humanist use of history - in the form of historiography - as moral and/or political guidance for the present.

Talbot and Bedford's awareness and use of history is motivated by "public" values - the defence and maintenance of conquered Freneh territorys and thereby the glory and reputation (itself historical in nature) of England. The good of the country, the common weals is of prime importance. These values, however, are shown early in the Henry vI sequence to be in decline: and have all but disappeared by the end of 1 Henry vi. The use of history that gains ascendancy is as a device complementary to personal advancement. History becomes a tool for personal (antisocial) political advantage" a vehicle for legitimation, rather than a guide for public (social) behaviour. Actions may still carry the facade of the old values, but selforientated motives are the actual catalyst and selfish goals the main incentive.

The character through whom we can trace this "personal" use of history is Richard Plantagenet as he pursues firstiy 
his status as Duke of York, and then his Elaim to the kingship of England. To make this claim valid requires the establishment of legitimacy that only history can provide. To obtain this he must first be rid of the historical "blot" held against the House of York due to his father's treasonous behaviour, then use history to establish the Yorkist elaim to the throne. The "blot" is readily removed by king Henry" "Fise, Fichard, like a true Plantagenet, / And rise created prineely Duke of York" (I Hemry W. III.i.1.74-175), while the York claim is established by way of Fichard's dying uneles Mortimer" who upon recitation of his own gemealogy and right to the crown, passes this claim to Richard: "Thou art my heir. The rest. I wish thee gather" (II "v"96). Fichard now has historjeal justifieation for his subsequent actions.

By 2 Henry Wy the Duke of York, as he is now titied, has his sights set firmly on the crown, in support of which am he ean recite his own "title" / Which is infallible, to the English crown" (II.i. "4-5) "This recitation of York's "title" proves 1 ong and convoluted" almost impenetrable: as noted by warwick in his ironie "What plain proceedings is more plain than this?" (1.53). The point is" however" that such visible knowledge, even masterys of history" is necessary for any elaim to be seen as viable and/or $1 \mathrm{eg} \operatorname{timate}=0$

\footnotetext{
aThis situation is similar to the Arehbishop of Canterbury's use of history in Henry y (I.i.i) where he recites a history of French salic law in order to legitimate his king's clam to France. For a discussion of this soene and its underlying tensions see chapter 3 . p 1.2.tf,
} 
This aspect of history suse is graphically illustrated in the York-instigated; Cade-led, rebellion. York has "seduced a headstrong Kentishman, / John Cade of Ashford" / To make commotion, as full. well he cany, Under the title of John Mortimer" (2 Henry Wy, III. $.356-359$ ) in an effort to "perceive the commons" mind, / How they affect the house and claim of York" (11.374-375). What York is in effect doing is harnessing the connotative power of the historical name of Mortimer in order to gauge popular receptivity to his own political aspirations " Cadey the play proceeds to show, accepts and performs his role with alacrity.

Early in the rebeliton, in an exchange between cade and Sir Humphrey stafford, there is a demonstration of both the scope history offers for" such "personal" use, and the subsequent difficulty: even impossibility: of countering or discrediting such a use"

Cade: Marry, this: Edmund Mortimer, Earl of March, Married the Duke of Clarence' daughter. did he not?

Stafford" Ay, sir.

Cade: By her he had two children at one birth. Stafford: That's false:

Cade" Ay: there's the question; but I say 'tis true: $(I V \cdot i j .127-132)$

While cade is never presented as a realistic contender for the throne in the manner of, say. John Ford's Ferkin 
Warbeck $\quad$ (who exhibits the requisite authority for such a contention)" here, in this particular and peculiar situation" it is up to stafford to prove Cade wrong rather than Cade to prove himself right. The perception that history lends legitimacy is thus used by Cade, on York's behalf, to superficially validate his uprising.

The Henry UT plays, then, trace a shift in the use of history from the "public" "community-focused use as with Bedford, to the "personal", self-orientated use as with York. Where Bedford used history as a source of inspiration to serve the common good, York makes use of history as a device for personal legitimacy.z=

\section{The Contribution of Drama}

The scope that the dramatic mode of presentation allows for characterisation and/or character development seems to have offered shakespeare most in his treatment, in the Henry W sequences of the historical material he found in the Chronicles " Where the Chronicles are event focused and driven, Shakespeare as dramatist (and "historian") can dwell. on and explore features of character and personality

\footnotetext{
2x In his history play The Chroniche History of Perkin Warbeck, A strange Truth (1634).

arthis changing use of history is discussed further, in relation to Henry "y in Chapter $z^{\prime}$
} 
responsible for these events: $2: 3$ He thus provides his historiography with a further dimension, making it appear more realistic or verisimilar. History, Shakespeare seems to be concluding through this "new" emphasis on character, is both event and participant driven.

The particular participant whose characterisation I will address here is that of the sequence's titular character, King Henry VI. By characterising Henry as they do, the Henry WT texts are able to form a chain reaction of implicit consequences to explain their action: the character of Henry consequently affects his kingship which consequently affects the state of English affairs, resulting in what we see on stage

To establish this effect, the texts use three dramatic methods of characterisation:

1) Soli1oquies spoken by Henry.

2) Henry's dialogue and/or interaction on stage.

3) Commentary spoken by other characters on some aspect of Henry's person.

For discussion here, I will take a representative example of each of these three methods of Henry's characterisation and Show how they contribute in combination to the overall effect

z: In relation to this point, Larry 5. Champion, in Ferspective in shekespeare's English Histories (Athens: University of Georgia Fress, 1980), pg 53, states that "3 Henry bl is especially significant in confirming a commitment to a focus predominantly upon the character rather than upon action." 
of verisimilitude.

The soliloquy offers the most direct method of characterisation. Whether a character talks to him/her-self or directly to the audience" the dramatic device allows the innermost thoughts of that character to be aired. The character in question is freed from their public image and is thus able to suggest or express an "essential" " or privatey self. Henry has only one such solitary situation. a scene (II.V) interposed between others depicting the Battle of Towton in 3 Henry U2. Banished from the battle by Queen Margaret, his wife, and Clifford because he is a nuisance "swearing both / They prosper best of all when I am thence" (II. $\vee .17-18$ ) - Henry cuts a pathetic figure as hesits on a "molehil1" (1.14) bemoaning his life. We have already been shown, in the earlier play, the dramatic image of a man desperately unhappy due to the vocation thrust upon him:

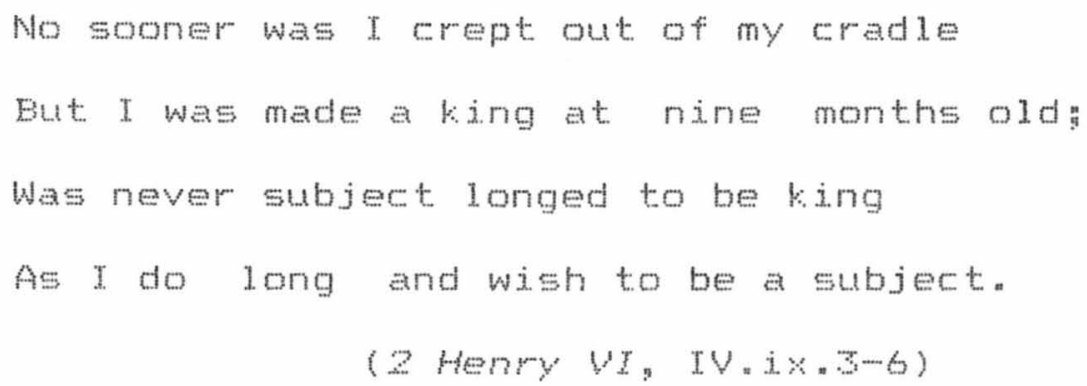

Now the "true" depth of Henry"s despair is made painfully evident as he dectares:

Would I were deady if God's good will were 50 ! For what is in this world but grief and woe?

$(3$ Henty W, II.V.19-20) 
It is the simple, uncomplicated life of the shepherd that Henry, characterised as a simple, uncomplicated man, yearns for : "Ah what a life were this! How sweet! How lovely!" (1.4x)" Henry ends his soliloquy with a comparison of his present life as king with that of the shepherd:

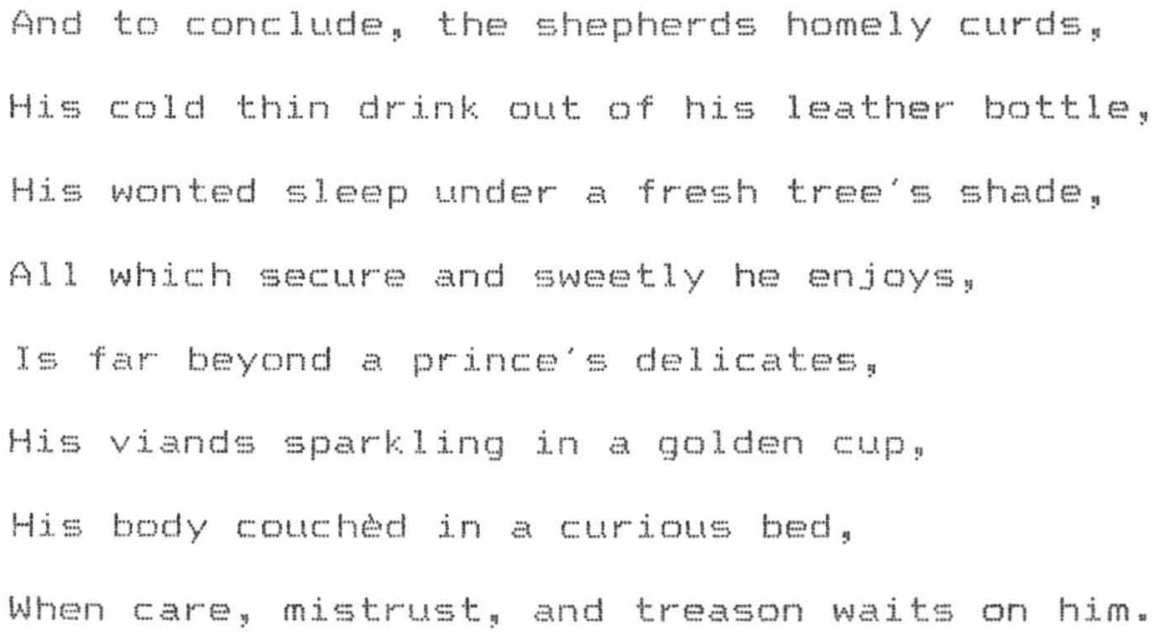

$$
\text { (II. V. } 47-54)=4
$$

Here is a man sadly out of his depth in a world of expectations he neither can nor will fulfil"

\footnotetext{
24This is similar in sentiment to Henry $V^{\prime}$ s comparison, also in soliloquy" of the life of a king and that of "private men" or a "slave" "

What infinite heart's ease

Must kings neglect that private men enjoy!

And what have kings that privates have not too,

Save ceremony, save general. ceremony?

$\because "$

No, not all these, thrice-gorgeous ceremony,

Not all these, laid in bed majestical,

Can sleep so soundly as the wretched slave.

Who, with a body filled, and vacant mind,

Gets him to rest, crammed with distressful bread. (Henty $V$, IV i . 229-232, * 259-263)
}

The difference lies in Henry $V$ 'sefusal to let this "private" belief override his performance of his public role to the detriment of the country. Moreover" there is little sense here that Henry wants to step down from 'kingsrip to exchange his role with a slave. 
While we may teel some sympathy here for Henry. the context of the scene -.. battle scenes both before and after Shows how the selfwpity of "Henry the man" has transgressed upon his role of "Henry the king" to the detriment of the country. The obvious conclusion is that the weakness of Henry, and thus his kingship, is the cause of the events around him $:=$

An episode in which Henry is characterised through dialogue and interaction is the scene of the Duke of York's return to England in 2 Henry W. Frior to this we have seen Henry prepare for York's arrival by committing somerset (who has been termed by York a "traitor", IV ix.so) to the Tower in an effort to defuse a potentially explosive confrontation: "For he [York] is fierce and cannot brook hard language" (IV.ix 44). These are hardly, jt will be recognised, the words or actons of an authoritative king who fears none but $\mathrm{God}$

Henry's panderings are momentarily successful: however: as York is indeed placeted by the news of somerset's imprisomment and proceeds to met. Henry "In all submission and humility" (V.i.se) " The seene is reduced to chaos, though: upon the entrance of Queen Margaret with the supposedly imprisoned Somerset; whose presence on stage speaks volumes as regards Henry's total lack of power and authority as king. Henry has been ignored, even over-ruled,

aHenry VI as the "primary" cause of events is discussed in section two " pp $37-38$, of this chapter. 
by somerset and, by implication, his wife "Henry's subsequent efforts at damage control are equally ineffective, and somewhat naive and childish, as he tells Buckingham to: "Go bid her" hide him quickly from the Duke" ( $V . i .84)$ "The Queen refuses, which causes York to launch into a vehement verbal attack on Henry -.. "False king!" (1.91) - and his ineptness:

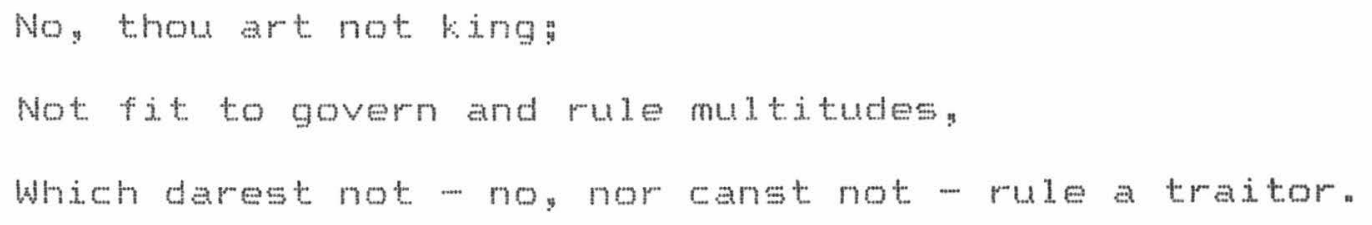

What York is implying here is that he (York) is "fit to govern and rule" - a conclusion he emphasises as he proceeds to rage against Henry, basing his argument on the symbolic trappings of kingship. As regards the crown, Henry's head "doth not become a crown" (1.96). whereas for York "That gold [crown] must round engirt these brows of mine" (1.99). Henry's hand is "made to grasp a palmer's staff, / And not to grace an awful princely sceptre" (11.97-98), while York has "a hand to hold a sceptre up, / And with the same to act controling laws" (11.102-103). York also pronounces that with his "smile and frown" (1.100) he "Is able with the change to ki11 or cure" (1.101). York's mival claim to the kingship of England, then, is based on his natural, intminsic, and physical ability to be and appear "1ike a 
king" (1.29), the very thing Henry is unable to donzes

At the conclusion of this outburst York receives a rejoinder not from Henry himself but from somerset. It is significant, in terms of the characterisation of Henry and his kingship, that between Henry's plea to the Queen to hide Somerset and his next speech to clifford, there are fortyeight lines of bellicose dialogue, and the armies of York (with his sons Edward and Fichard) and Lancaster (with Clifford and Young Cifford) enter the arena, all under his gaze. Henry's silence while others take control and speak for him reflects on his character as both king and man. The nature of his interaction, or lack of it, with those around nim helps to characterise his reign, as does the state of affairs apparentiy under his jurisdiction a

An example of the third dramatic method of characterisation, that of commentary of others on some aspect of Henry's persony is supplied by Henry's wifes Quen Margaret, early in 2 Henry W (I.i.i). Margaret. who before

sothe type of kingship York seems to suggest here is that identified by David Scott kastan" in "Froud Majesty Made a Subject: Shakespeare and the Spectacle of Fule". Shakespeare Quarterly, 37 (1986), pg 469, as "rule as role" whereby "power" passes to him who can best control. and manipulate the visual and verbal symbols of authority." Henry. then, is losing his power through his inability to perform such a "role".

aThis state of affeirs is reflected in the chorus's "Epilogue" to Henry W"

Henry the sixth: in infant bands crowned king of France and Englandy did this King [HV] succeed, Whose state so many had the managing

That they lost France, and made his England bleed. (Menry V: Epilogue, 9-12) 
coming to England thought Henry would resemble her escort suffolk "In courage, courtship. and proportion" (I.i.i.52), found instead that Henry is more priest than kings and in no way meets her expectations:

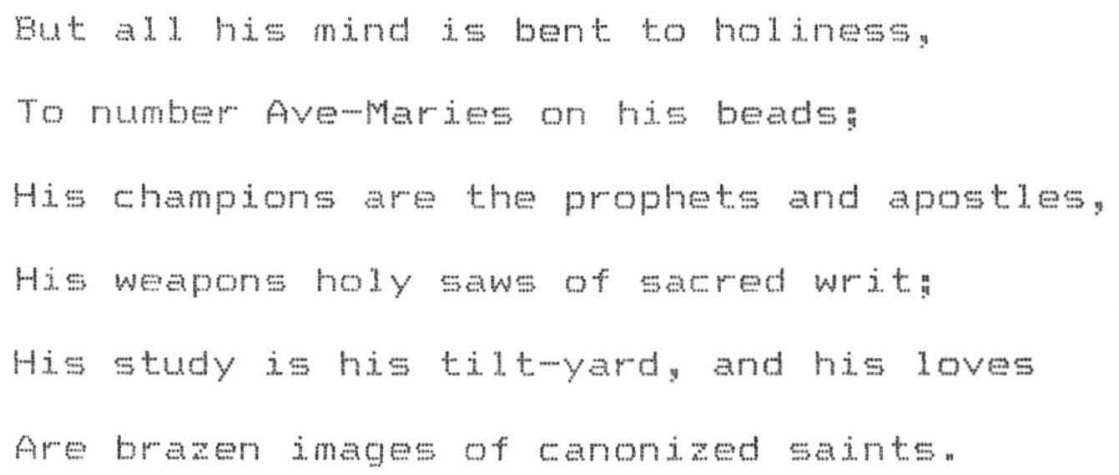

$$
(I . i . i .53-58)
$$

Margaret continues to suggest a more suitable vocation for Henry, albeit one tinged with bitter sarcasm:

I. would the College of the Cardinals Would choose him Pope, and carry him to Rome, And set the triple wown upon his head That were a state fit for his holiness"

$$
\text { (I. i.i.i. } 59-62)
$$

Margaret's speeches, then, characterise Henry as an excessively pious individual, more concerned with divine than temporal matters, and lacking those admirable physical. quadties ghe sees in suffolk qualities which. to her mind, should be duplicated in a king.

Serving as an effective comparative and concluding point in this discussion of the dramatic methods of characterisation in the Henry Wr sequence" and the way they 
contribute to an overall effect of historical realism and verisimilitude, is the brief appearance of Fichmond in At IV

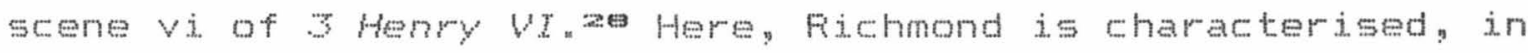
miniature, solely through the commentary of others. He is given neither dialogue nor interaction, and he utters nothing in soliloquy or aside. He therefore appears as no more than a one-wimensional dramatic caricature when compared with such charatters as King Henry VI, who are not only talked about, but talk, interact, and (through soliloquy) think on stage. It is the combination of these three dramatic methods of characterisation -.- soliloquy, dialogue and interaction, and commentary - that give a more rounded and complete version of a character. The Henry WI textsy and shakespeare the "historian" lift historical characters from the chronicles and bring them to "1ife", lending their character and personelity some visible consequence in the moment of history in which they take part. $a$ a They are fleshed out. which helps to make character as much a part of history as event.

Shakespeare's dramatic historiography as exemplified in the Henry Wh sequence, then, is a "realisation" of the history found in the Chronicles with regard to both character and event. However" as we have seen in connection with the Countess of Auvergne - Lord Talbot episode of 1 Henry Wr.

apiscussed earlier" in relation to the "Tudor Myth" in section two. pp $39-40$, of this Chapter"

aAs F" Smith Fussner, pg 229, argues: "Shakespeare's contribution to Elizabethan ideas of history" " was historic verisimilitude" probable, live kings; not player kings dressed up from the chronicles" 
Shakespeare's dramatic historiography also evinces the first signs of a self-reflexive awareness that its "realisation" is anything but "real" in terms of (re)presenting the historical "truth" " 


\section{Fichard II and oral History.}

Sir Thomas More's History of King Richard TII, written around 1513, provides the seminal portrat of the king dramatised in shavespeare's history play Richard $I I I$. It meached Shakespeare not directly, but through a long chain of mesengers:

The story, as Shakespeare read it in Hall and Holinshed, traces back to two early sixteenth-eentury accounts, More's life of Fichard (Latin and English) and Folydore Vergil's Anglice Historia, neither of which he himself seems to have looked at. Later chronicles borrowed freely from these two mear-contemporary historians, and from each other" in the usual manner of the time. Fichard Grafton (1543) used bothy and was himself plundered by Hall (1548), from whom Grafton then extracted more bits and pieces for his second version (1569). Holinshed, finelly, drew upon More: Polydore Vergi.1, Ha11, Grafton, and others. ${ }^{2}$

This passage through the sixteenth century of the historiography of Fichard III from "original" historians (More, Vergi.1) to chroniclers (Grafton, Ha11, Holinshed) to

1.E.A.J. Honigmann, "Introduction", $p g 13$, in his edition of Shatespeare"s King Richard the Third (Middlesex: Penguin Books: Ltd, 1986). 
dramatist (Shakespeare) is an example of the Tudor mistoriographical practices of adaptation and accretion.z What is immediately evident is the similarity between the transmission of ideas and information from author to author through written historiographys and the transmission of the same by way of speech from one person to another: that is: oral transmission. More's History as one of the founts of this particular strand of (written) historiography, is itself a product of the oral transmission of historical detail. Through the History More writes of what men "say" "what he has "heard" and what he has "learned" : In Paul Murray kenda11's words. More's History is:

a manuscript which is based on oral information gathered a generation after the event.4

We therefore have the interesting phenomenon of the historiography of Fichard III being grounded in the tradition of oral history.

The fact that More's History occupies such a pivotal position, linking oral and written history, and exerts such a direct intluence on the historiographic potrayal and subsequent popular perception of Richard II is cause to look

\footnotetext{
2These practises are defined on pg 15.

sir Thomas More" History ot King Richard III (ed. P.M. kenda1. " in Faul Murray kendall. Fichard IIT - The Great Debate (New York: W.W. Norton a Company, 1992), pg 36, 103 : 106. A1 subsequent quotes are taken from this edition.

4 kenda11: pg 26.
} 
briefly at the problems involved in the transposition of "oral information" into authorjtative historiography.

The main problem in such a transposition is that of source: for" as the authors of oral History - A Handbook put it: the "Achilles heel of oral testimony" "Lis] the unlinited potential for distortion "s The historian must. when surveying his collected "oral testimony" "try to do as Chaucer"s Nun's Friest advises" "Taketh the fruyts and 1 at the chaf be stille." If information is sourced from a particular informant, distortion may be due either to genuine human error (the unintentional confusing or forgetting of mames " details, or places) or, conversely, to deliberate manipulation (intentional distortion of facts to serve a personal agenda, portraying someone or something in a better or worse ijght than is the case) " Furthermore, and transending these intentional and unintentional factors. there is the distortion that would result from an individual's personal perspective and unconscious ideological position(s)" Therefore, the "truth" or accuracy of any report js in Hersehel Baker's words subject to:

not only convictions and beliefs, but also attitudes, assumptions and contigurations of opinion that were bound to shape a man's perception and thus his

mouise Douglas, Alan Roberts, Futh Thompson, Ora2 History

-. A Habolk (Sydney: Allen k Unwin. 1.988) " pg 20.

ochaucer" (ed. Benson), "Nun's Friest."Tale" 1.3443. 
Of the above the intentional distortion of "facts" wherein a source" or indeed the historian, has some vested interest in popularizing a certain perspective on events - is a strong consideration when dealing with the controversial and provocative figure of Fichard III in combination with the political propaganda of the Tudor dynasty (in such forms as the "Tudor Myth"). It is in Tudor interests to present Fichard as an unequivocally evil king who in the best interests of England: was justifiably overthrown.

This Tudor interest may also affect the other source of oral. information available to the historian, that of the public domain. Information here will span the spectrum from "factual event" to 1ies, with legend, myth: gossips rumour and speculation in-between. The historian must try to filter this and somehow extract mly that whichn in his judgement. adds to" or bears upon, what $i s$ almeady known. In all of the above, the pessing of time - More: it will be remembered, is writing a "generation after the event" - is a huge consideration to be taken into acount. In the intervening years stories whith perhaps began as the most outrageous falsitications may, through endless repetition, assume an unjustified eredence" In summary theng the oral historian must be aware that all attempts "to give an account of what has mappened." will be subject to interpretive

\footnotetext{
Herschel Baker" The Pace or Time" Three tectures on Fenassance Hiskorography (Toronto University of Toronto Fress, 1967), pg 23.
} 
reconstruction, "s some, of course, more than others.

Both More and Shakespeare, in their respective works, seem to illustrate an awareness of the various problems and pitfalls involved when compiling and presenting orallysoured historiography " A representative and comparable episode from each - the subject of Fichard's birth - will make this telear.

In More's character sketch of fichard, he describes Fichard"s physical appearance" "1ittle of stature. il. featured of limbs, crook-backed, his left shoulder much higher" than his right" (pg 35)" and aspects of Fichard's personality" "He was malicious" wrathful, envious" (pg 35)" He then touches upon the subject of Richard's birth. Significantly: More prefaces these details with "It is for truth meported" (my emphasis), distinguishing what is to follow from the preceding information regarding appearance and personality which, unprefaced, therefore stands as the truth. This seems to indicate that More feels less comfortable with either his sourese(s) or the information itself, and so adds a mall disclaimer suggesting that what foll lows may or may not be true:

It is for truth reported that the Duchess his mother had so much ado in her travail that she could not be delivered of him uncut, and that he came into the world With the feet forward - as men be borne out of it -- and

wouglas etal, pg 21. 
(as the fame runs) also not untoothed."

There is: then, an implicit distinction made between true report and that which stands "for" the truth. details which accumulate around a popular figure as speculative "fame" "The passage then continues with two possible reasons for the existence of this report or "fame"

either men out of hatred report above the truth [i.men 1.je] or else nature changed her course in his beginning who in the course of his life many things unnaturally commited 10

If More himself subscribes, and expects his readers to Likewise subscribe, to the former explanation of a false report made out of "hatred" rather than the latter explanation that "nature changed her course", then the inclusion of this latter explanation lends the impression that it was made for (prudent) political reasons. Realising that to question the truth of the popular reports" or "fame", regarding Richard's birth is to question the basis of the Tudor Myth cone dubious story may taint or tarnish the whole), More gives himself an escape clause in allowing the possibility that fichard was a freak of nature " on the other hand: however: More may simply have included both explanations to signify his historical accuracy and completeness, showing that he is giving a rounded account of his:subject by not leaving anything out, even details which

\footnotetext{
More, pg 35.

xomore: pg 5.5
} 
birth are an example, recognised by More in his qualification "as the fame runs" and his reference to "hatred", of the distorting effect oral report can have upon historical "truth", especially when influenced by (Tudor) political interest.

The details of Fichard's birth also seem to be used in Shakespeare's Richard IIT to illustrate the discrepancies to which the oral tradition can lead when reported "truths" (More's "fame") gain popular currency" In a brief exchange between the young Duke of York and his grandmother the Duchess of York (Richard's mother'), the topic of Richard's birth is raised x.x.

York: Marry: they say my uncle grew so fast

That he could gnaw a erust at two hours old:

x.This exchange between York and the Duchess recalis one of similar content in 3 Henry $W$ where the soon-to-bemurdered Henry VI addresses his soon-to-be-murderer Fichard:

Thy mother felt more than a mother's pain, And yet brought forth less than a mother' 3 hope, " " " "

Teeth hadst thou in thy head when thou wast born. To signify thou camest to bite the world: And if the rest be true which I have heard, Thou camest - [here Henry is halted by Richard] (3 Herry Vy, V.vi. 49-50, " s3-56)

Significant here is that Henry has "heard" these and more details concerning Fichard's birth, thus showing them as part of the oral tradition. It is also significants in terms of illustrating the "Chinese-whispers" distorting effect oral history may be subject to" that Henry's version has Fichard "born" with teeth. while the young Duke"s later version has Rithard growing "so fast [and implicitly growing teeth so fast]" that he was able to "gnaw" at "two hours old" " 
Duchess: I prey thee, pretty York, who told thee this?

York: Grandam, his nurse.

Duchess" His nurse? Why, she was dead ere thou wast born.

Vork: If 'twere not she, I cannot tell who told me "

$$
(\text { II. iv. } 27-28 \cdot .31-34)^{12}
$$

The similarities with the previous passage from More's History are obvious. More's "It is for truth reported" becomes here "they say", and the play turns the report of being "not untoothed" into the more graphic and memorable detail of being able to "gnaw a crust" "Some elaboration upon the source of the Duke's information, his "they say" is sought by the Duchess, who in so doing seems to imply the untruthfuness of the report: the situation of the Duchess enquiring of her grandson what is sad of her son's birth is quite absurd, for surely the mother" if anyone, would know the "truth" of the matter. In reply the Duke first names his source as fichard's nurse, but this is quickiy proved impossible by the Duchess, causing the Duke to become equivocal" "If "were not she, I cannot tel1 who told me" The Duke's story, then, is unsourced and exists of itself: perhaps lent some undeserved authority through its popular ascription to the now dead nurse, an indisputable source. What the above exchange illustrates is how a story/rumour circulates and, upon entering the public consciousness" questions of source and truth fade into the background. In

\footnotetext{
12william Shakespeare, King Richard the Third, ed. E.A.J. Honigmann (Middlesex: Fenguin Books Ltd, 1986) "All subsequent quotes are taken from this edition.
} 
Jan Vansina's words:

Fumours that are not contradicted survive and become part first of the store of oral history, later also of oral tradition $x=$

What it also illustrates" through Queen Elizabeth's abrupt rejoinder "Pitchers have ears" (1.37" a rejoinder which also indicates her anxiety at being overheard discussing such matters): is how a story/rumour infiltrates society to be randomly heard and subsequently repeated by even the smallest "pitcher", here equated with the young Duke" The oral tradition does not discern who plays a. part in its $\operatorname{transmission}$

Elsewhere in the History" Sir Thomas More is often at pains to stress the reliability of his sources and consequently the truth of his received information. This also has the effect, however, of implicitly acknowledging the possibility of his sources being unreliabley especially when we bear in mind those pitfalls to which the oral transmission of history is prone. More"s concern with the authoritativeness and impartiality of his sources is particularly prominent when he is dealing with such disputed cases as that of the murder of the two princes. Here, More states his sources are those who "much knew and little cause had to lie" (pg 106). His information regarding the effects on Fichard of the murder ("he never had quiet in his mind" "

\footnotetext{
1. Jan Vansina, Gral Tradition as History (London" James Curry Ltd, 1985), pg 6.
} 
"He took ill mest a-nights" "pg 107), he tells us. was "heard by credible report of such as were secret with his chamber-m men" (pg 107) " In the former statement. "1ittle cause" "to lie" does not entirely mule out falsification: while the latter statement" "credible report" is at best third hand information. Every mention of the historiographer's oral sources and their reliability only draws attention to the essential unreliability of such sourese for the historian.

This juxtaposition of the written and oral, which raises the question of the best vehicle or conduit for historical "truth" is the subject of a conversetion between prince Edward, Buckingham, and Fichard in Richard III (III. . $61-88$ ). Prince Edward wants to know where he and his brother will "gojourn till our coronation" (1.62)" to which Richard suggests that "the Tower" (1.65) will suit for a couple of days. Talk then turns to the subject of the Tower. its history, and the role played therein by Julius Caesar". The young Frince asks Buckingham how he knows Juldus Caesar began the bujlding of the Tower" "Is it upon recordu or else reported / successively from age to age he built it?" (11.72-73) " "Fecord" here equates to the written word, and is linked therefore with written historiography" "reported." from age to age" equates to the spoken word. hence oral history. Burkingham's statement that the Tower's history is "Upon record" (1,74) receives an interesting reply from the Fince:

Eut say my lord: it were not registered [recorded] Me thinks the truth should ine from age to age: 


\section{As 'twere retailed to all posterity. \\ Even to the general ald-ending day.}

(III. I. $.75-78$ )

The assumption both the Frince and Buckingham seem to be displaying here is that those historical details "registered" that is, recorded or written, are subsequently accepted as the "truth" "The fact that Julius Caesar's part in the building of the Tower" has been "registered" means it is recognised as the "truth", and, using the prince's words out of context. "should live from age to age" "The consequences and implications of this conceptualisation of written history for the historian, especially an oral historian like More who creates a written record out of oral reports are huge. Those reports chosen or selected, for whatever reason and at a certain moment in time, as worthy of becoming record ("registered") will be accepted as the "truth", the dialogue suggests, long after the historian, his sources: and any others in whose living memory the events in question occurred, have passed away. As an example of this we need only remember the whole-hearted acceptance of More's historical record by Hall and Holinshed.

The Frince's speech, however" merely suggests the above " What he actually says is that had Julius Caesar's involvement with the building of the Tower - here standing for the "truth" - not been "registered", the "truth" would have still survived and be known as such. "Registration" "then, is not necessarily a corollary for the "truth" to be known. It may just as easily, says the princes be "retailed to all 
posterity" as (oral) report. Taken a step further, there is no reason why report should not more closely approximate the "truth" than does record. The Prince's essential premise is that the "truth" wi.1. "somehow" always be known.

What, then, does this strange little interchange mean, and why incoporate a diswssion of oral versus written "truth" in a staged production (which participates in both "oral" and "written" traditions)? I think the text is presenting this discussion of Julius Caesar"s involvement in the building of the Tower as an analogy for Fichard's involvement in the murder of the two princes in the same Tower. It suggests that while there are no written records incriminating Fichard of the crime, the "truth" of the matter -.. that Richard was the instigator - is "known" regardless. In the process, the text is legitimating both More's (re)construction of the murder, itself devised from, and a transcription of, oral testimony, and those other unwritten or un-"registered" reports which implicate Fichard in the murder. Though there is no written proof, only verbal and incidentel report: the "truth" will still be known through the ages. Fichard himself suggests this when he answers the Prince: "I say, without [written] characters fame lives long" (1.81) "Soon after this "the Julius Caesar analogy comes to a wose with the frince reflecting on how Caesar's "valour" (1.85) hes ensured his "fame" (1.89), leaving us to reflect on the "fame" - or infamy - of Richard. 
In her "Author's Preface" to The Princes in the Tower: Alison Weiry while discussing the unlikelinood of any confirmetion of the "truth" concerning the murder of the two Frinces (Edward and Fichard)" compares the difficulties facing the historian in such a wase with those faced by a 1. awyer" "

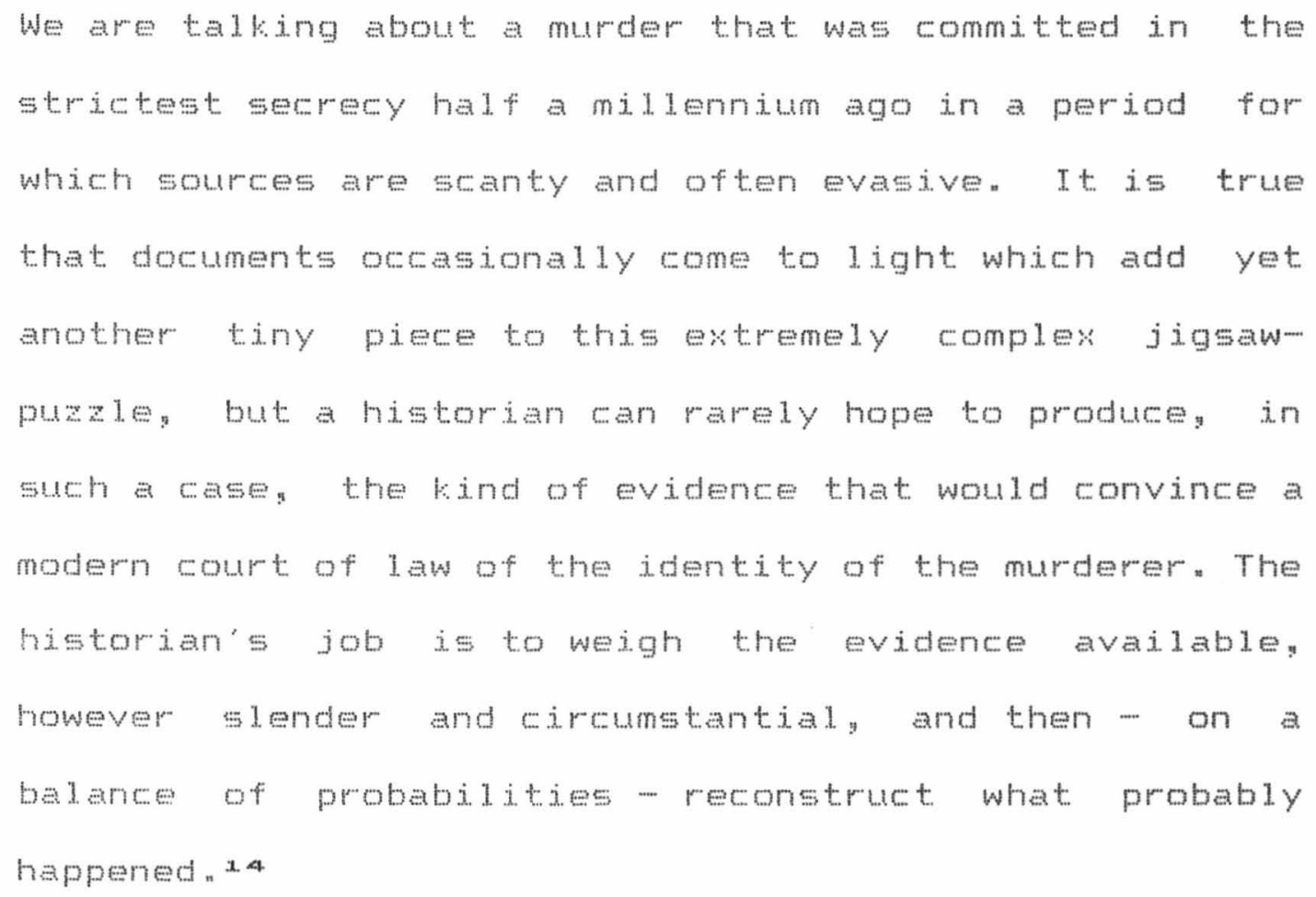

While weir is here talking of the "modern court of 1 aw" and the "historian's job" as it applies to her" own task. we can equaliy apply the analogy of historian and lawyer to $5 i r$ Thomas More and william Shakespeare as they "reconstruct" their respective histories of Fichard III. It is interesting to note that More was himself; alongside his historical and

4Alison Weir" "Author"s Preface" in The princes in the Tower (London: The Bodley Head; 1992), pg xi.i.- 
political interests, a legal professional. He was a trained lawyer "acclaimed for his skill in law", and his vocation at the time of writing the History of King Richard III was that

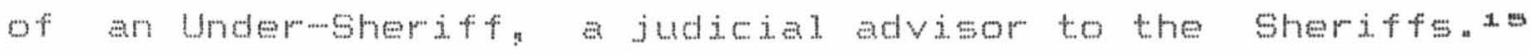
The lawyer -- historian analogy is thus embodied in the figure of Sir Thomas More. Consequently, we might expect More's historiography and the historiographical methods evident in the History to be influenced by his knowledge of the law and its practices and procedures. Likewise, through its derivative nature, Shakespeare's Richard TIT.

To examine this proposed contiguity between the pursuits of the lawyer and the historian! I will take the above passage from The Princes in the Tower, point by point, and discuss it in relation to the two texts under consideration here Chakespeare's Richard III and More's History of King Ficherd $(X I)$.

Weir's first point - that the murder of the Frinces was a highly secret and covert operation leaving no overt incriminating evidence ("sources") --is suggestive of the situation facing the lawyer and historian alike, that of starting their process of discovery from the end result. From the actual event and from the person accused, they must uncover the probable "truth": the causes and motives. They must, in Katherine Eisaman Maus's words, extract from

\footnotetext{
x senda1. "pp 23-26"
} 
"external appearances" the "inner" invisible truth" 16 This task is, of course, impossible. The hidden causes of an event and the internal motives of a person can only be brought to light through the practice or process of what Maus terms "induction." " reasoning from the superficial to the deep. from the effect to the cause, from seeming to being." This process is always " however" "liable to error" "1. Significantly, Sir Thomas More, lawyer and historian, acknowledges this very practice and the uncertain conclusions the process is likely to yield. Reporting the dispute over Fichard's involvement in clarence's death (discussed later), More dec 1 ares:

But of all this point is there no certainty, and whoso divines upon conjectures may as well shoot too far as too short. 1.

Conjecturing or inducing a "truth" then, is fraught with problems: the outcome is as likely to miss the mark as hit i.t.

The practice of induction, of discerning or extracting an "inner, invisible truth" from "external appearances", is further problematised, but also made more necessary, when the defendant in a trial or the subject of a history is allegedly

\footnotetext{
1. 6 katherine Eisaman Maus, "Froof and Consequences: Inwardness and Its Exposure in the English Fenaissance", Representations 34 (Spring 1991), pg 29.

1.7Mas, pg 36.

x.more. $\mathrm{pg}$ B.
} 
or reputedly one whose speech and actions are. a misleading facade. Richard is just such a character in More's History. Here, Fichard is described as:

close and secret, a deep dissembler: lowly of countenances arrogant of heart, outwardly companionable where he inwerdly hated not hesitating to riss whom he thought to ki.1. 1.24

of note here is the use of terms like "inwardly" and "thought" and the emphasis on the dissembling nature of the man "

Shakespeare's texts are able to display the duplicitous nature of Fichard more pointedly (in the manner of the vice of the morality play tradition) through their juxtaposition of Fichard's "inner", invisible truth" in soli.loguy and aside with that of his "external appearances" in stage (inter)action, thereby drawing attention to the discrepancy between the two. Alone on stage soliloquizing or in an aside, the texts illustrate why the lawyer's and historian's inductive processes will, when applied to Fichard's "external appearances" "prove fruitless. In 3 Henry VT Riehard outlines his ability for deliberate deception and deceit:

Why, I can smiles and murder whiles I smile: And Ery 'Content!' to that which grieves my heart, And wet my cheeks with artificial tears, And frame my face to all occasions.

\footnotetext{
1. More: Pg 35
} 
Later, in Fichard $r T$, Fichard outlines his technique of cloaking his "naked villainy" with superficial emotion and piety:

But then I sigh, and with a piece of Scripture. Teli. them that God bids us do good for evi.1; And thus I cloth my naked villainy

With odd old ends stolen forth of Holy Writ. And seem a saint, when most. I play the devil.

$$
\text { (I. ii . } 333-337 \text { ) }
$$

A virtuoso performance of this technique is given in Act III scene vii, where Fichard, entering above holding his prayer book and flanked by two bishops receives the pre-planned supplication of Buckingham to be king before the Lord Mayor and citizens of London. Only after twice refusing: nominally because he is "unfit for state and majesty" (III.viin204), does Fichard "grudgingly" accept the responsibility of kingship.

These examples of Fichard revealing his capacity to belie his "inner" invisible truth" with contrived "external appearances", then, have the self-reflexive effect of undermining induction as a legal and historiographical method of obtaining the "truth" " They show the potential impossibility of either knowing or discovering someone's thoughts, feelings or intentions. Without Fichard revealing to us this "inner" knowledge - which is itself, of course, a poetic invention of the dramatist - we would be left to 
guess: calculates or induce what lay behind his outward behaviour" exacty the situation in which a prosecuting lawyer, for example, or a historian, would find themselves.

In the last sentence of the quotation from weir's "Freface" -.. that which outines the "historian's job" of weighing the "evidence available" to "reconstruct what probably happened" -- what is immediately apparent is the subjective nature of the nistorical (and legal) process. and the active role the historian pleys in the historiography they present. A lawyer: ejther for the prosecution or the defence, must select only that evidence which serves, or is appropriate to. his particular persuasion. The historian. With the overall intention of trying to "convince" others thet his account is the "truth" must "weigh the evidence available" and then, through prudent selection, construct the most probable portrayal of character and event. The historian, therefore, like a lawyer, is stating a case - a similarity which is even more pronouned if the historian sets out not to show the "truth" but to either glorify or vilify his subject. If, in the wase of Fichard III for example, a historian wanted to emphasise fichard's villainy or has a (pre)conception of fichard's guilt, then only that evidence which suits, or is expedient to this particular emphasis, would be selected. Such selections, be they biased or impartial, are all made subjectively with the intention of either discovering and repeating the "truth" or moulding selected evidence to fit a certain viewpoint fand one may be indistinguishable from the other). 
The extensiveness and amount of evidence the historian has to work with, or "weigh", is also an issue raised by weir" in her qualification "however slender and circumstantial" " Regardless of the shortage or inconclusive nature of the evidence, some conclusion must still be reached or postulated. To this end" the historiographical process reflects that of the English Renaissance law-court where:

circumstantial evidence was al that was required for conviction. English courts made no rules about the admissibility of evidence, no qualitative distinction among kinds of proof: until. well into the seventeenth century. The power to convince the jury was all that mettered $=0$

Significant here is Maus's recognition of the legal prioritisation of the (rhetorical) "power to convince" over any reliance on "proof" "Circumstantial evidences in combination with the persuasive use of eloquence and/or emotional appeal (for pathos or sympathy, for example)" is al that is required to construct and plead a casen This situation can equally be applied to the historian. Their task, in Weir's words; is "on a balance of probabilities -[to] reconstruct what probably happened" "Like the lawyer. the historian must "reconstruct" from the available evidencey circumstantial or otherwise: a probable and convincing (narrative) account of an event.

zomaus, pg 32. 
Such reliance on circumstantial evidence draws out the similarities between the legal and historiographical processes and practices in Feneissance England. Both are: in the first instance, concerned with discerning or discovering an "inner" invisible truth" from perceived or known "external appearances" a process which is, by definition, impossible. This necessitates the use of "induction" which in effect may be no more than educated speculation. The yield from this process of induction is then reconstruted and formulated into a rhetorical narrative which is most likely to persuade a judge, jury: or reader" The issue of "truth" seems to become secondary.

It is interesting to observe now, in More's History of King Richard III and Shakespeare's Fichard III, 1 egal practice and/or process is used or abused to establish or mepresent the "truth" and thereby to observe how this reflects the practice and/or process of the historiographer as he or she also sems to portray the "truth" "In so doing we bear in mind Maus's conclusion that:

The English Fenaissance theater" and the Shakespearean theater perhaps most self-consciously struggles like the English Femaissance courtroom with the 1 imitations and potential falsifications involved in the process of making visible an invisible truth. 21

The courtroom, the theatre and historiography, then, in

\footnotetext{
2xMas.pg 47.
} 
having the similar objective to persuade their respective audiences of the "truth" are subject to similar problems. These are further agravated when the defendant or protagonist or historical subject is duplicitous and selfconsciously aware of the "limitations and potential falsifications" of the search for "truth" "How do More (in prose as lawyer and historian) and Shakespeare (in verse drama as dramaturgical historian), themselves seeking to portray a version of the "truth", represent Richard's supposed distortion of the "truth" and "truth"-baring proceses? Two episodes" or "cases" "are particularly interesting in relation to this question: the circumstances surrounding the accusations of treason aimed firstly at Clarence, and later at Lord Hastings.

clarence's downfall in the History is initially attributed to one of two possible causes: either the jealousy and envy of the Queen and her Woodville faction, or Clarence's personal pride and ambition:

For were it due to the Queen and the lords of her blood: who highly maligned the king's kindred. " or were it due to the proud appetite of the Duke himselfs intending to be king heinous treason was laid to his charge[. ] $=$

More here gives no indication which of these he believes is the most probable, or worthy of more weight, merely continuing with a report of the subsequent judgement and

zamore, pg $34-35$. 
sentence:

and finally -. were he faulty were he faultess attainted was he by Farliament and judged to the death, and thereupon hastily drowned in a butt of Malmesey. $z$ s

The association here of the charge of treason with the difficulty of discovering actual innocence or guilt - "were he faulty were he faultiess" - is indicative of the legal and historiographical problem, discussed aboves of ascertaining "inner" invisible truth" from "external appearances" "This" however" was what some charges of treason reguired. In the medieval treason statute of 1352, which provided the basis for treason law in subsequent years through to stuart times, a4 one of the various offences Eassified as treasonous was "to compass or imagine the death of the king, his queen or the royal heir" "as The offence, then, might be committed in thought or intention as well as in deed, and as such is difficult, even imposeible, to know or prove. As regards Clarence's wharge of treason as reported by Mores the suspicion that he was "intending to be king", thereby necessitating the removal of the current king, Edward

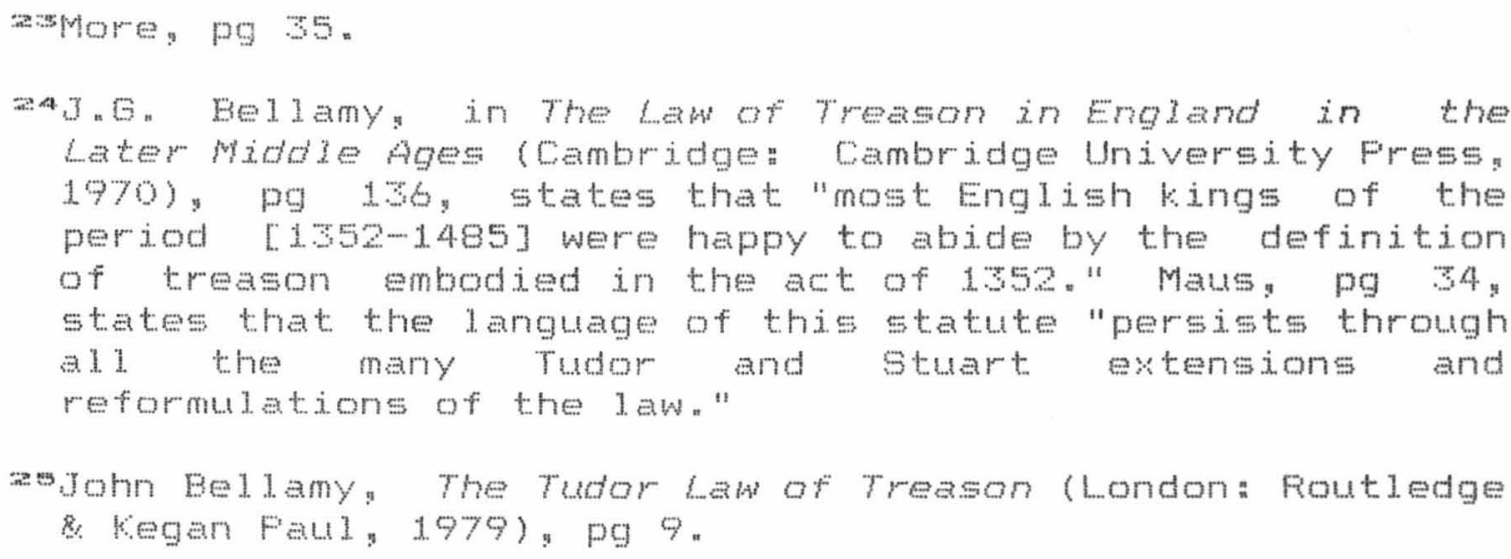


IV, would tal1 within the bounds of "compassing or imagining the death of the bing" "Henes the necessity of "induction" (to ascertain any "compassing or imagining") to such a charge of treason, and henee ultimately no abeolute "knowledge" of fault - "were he faulty, were he faultess"

of significance in More'shistoriography (above) is his use of legal terminology and of 1 egal procedure" "tharge" " attainted" "judged" "These details; however" which serve to lend his account of Clerene's trial some sense of overt propriety: seem guite incongruous when juxtaposed with the maner of clerence"s execution" "hastily drowned in a butt of Malmesey" we are left by More to wonder at both the haste and the particular and obswure method of drowning does this suggest some personal or political expediency relating to the cas?

These questions especially that of expediency in such a prompt dispateh of Clarence, are partly answered by More a 1.ttle later. It will be remembered that in More's account of Clarence's downtall. Fichard is neither mentioned nor implicated. Not so" however" when More meports what is thought at large concerning the case:

Some wise men aso think that his [Fichards] drift.
covertiy conveyed, lacked not in helping forth his
brother of clarence to his death" which he pesisted
openly, nowbeit somewhat (as men deemed) more faintly


than he that were heartily minded to his welfaren $=6$

The reason for this "wise" thought. is the obvious one that clarence's removal raised fichard's place in the line of succession to the wown, for "they that thus deem, think that he [Fichard] long time in king Edward's life forethought to be king" therefore Clarence"s "life must needs have hindered nim" (pg 3b). The overall effect here of an initial account followed by a secondary and partly contradictory report withy in wetween, the destription of fichard as a "deep dissembler", is to suggest that behind the "external. appearances" of Clarence"s "treason" is the "inner", invisible truth" of Richard's evil intentions. It therefore seems. through More's ordering and presentation of the "facts" that Fichard is using the "external appearance" of a treason charge: and possibly the legally ambiguous nature of "imagining" treason" to hide his own "innery invisible" desire for the crown "

In Fichard $2 I Z$, on the other hand, and carrying on from the closing scenes of H Henry big Fichard is unequivocally shown to be implicated in, and the catalyst for, clarence's imprisonment and death. His devious method involves the seting abroad of false prophecies to evoke fear and suspicion of Clarenee in his elder brother: the present king, Edward IV In the penultimate scene of z Henry VI Richard briefly outlines his plan:

- 6 More.pg 56. 
clarence; beware" thou keepest me from the light.

But I will sort a pitehy day for thee:

For I will buzz abroad such prophecies

That Edward shall be fearful of his life"

And then, to purge his fear, I' 1. be thy death.

( 3 Henry VI, V.Vi. $84-88$ )

By Richard $I X x$ the plan has slightly changed. Instead of prophecies causing Edward to fear for his own life, they will cause Edward to fear for the lives of his heirs, that is, his children. otherwise the plan, now more elaborately elucidated, is the same:

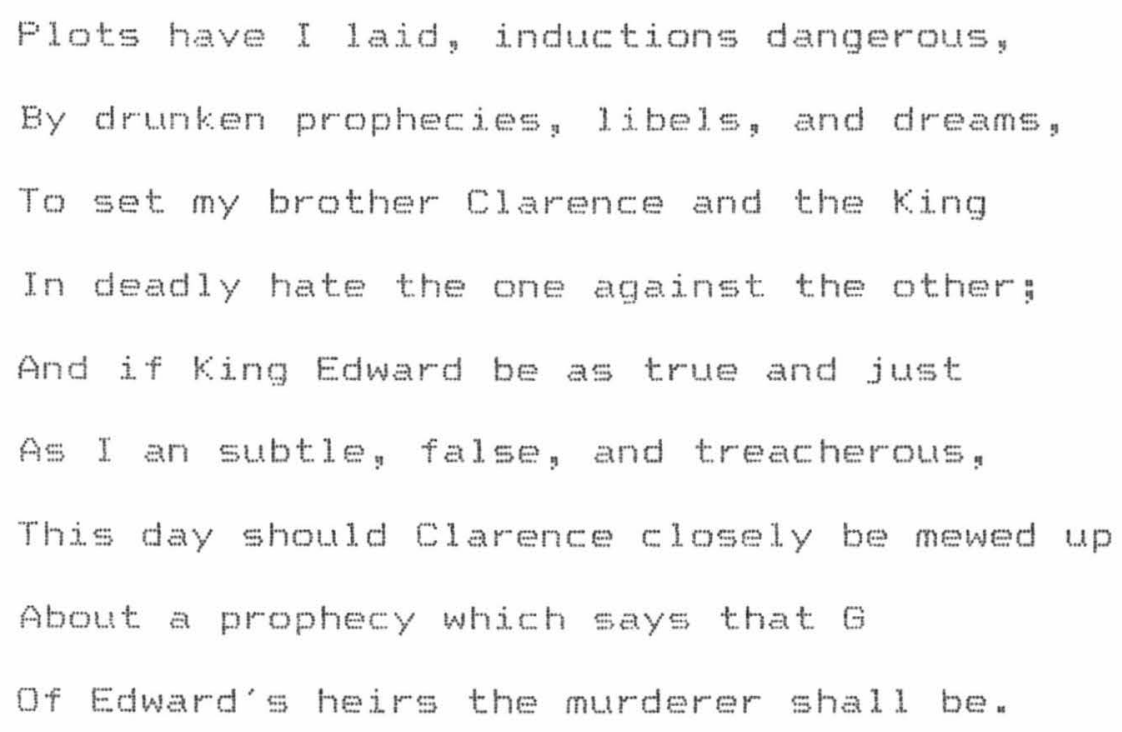


aseumed in the presence of othersar - something which More, the prosaic historian and lawyer, does not have recourse to.

Fichard plan, especially that as lad out in the second passage (Ficherd ITI), is interesting as regards our discussion for two reasons. The first is the use of "prophecies. libels, and dreams" w. what Fichard calls "inductions dangerous" - which all require interpretation for their meaning to become apparent. a prophecy"s "external appearanee" "its "inner. invisible truth" must be induced for it to have any credence. otherwise it is meaningless babble. Fichard sems to be aware of this he even supplies his prophery with an "inner" invisible truth" "since "G" can as easily be oloucester (himself) as

arshasespare's women characters" though" from dueen Margaret (her presence in the play being a poetic and dramatic liberty of the dramatist as Margaret had left England and died "prior to the main action of the play" Honigmann! pg 40)" "Look when he fawns he bites" (I.jij.289), to his mother, the Duchess of York" "Ah" that deceit should steal such gentleshape/ And with a virtuous visor hide deep viee!" (II.i.27-28), do recognise, in a similar fashion to the audience who view, Fichard for what he $i s$ "The women's intuitive understanding, however, is neither accepted nor reflected in the men's more physical ("external")" and thus deceivable level of understanding and operation.

awhe oxford English Dictionary (2nd Edition) cites this very passage to illustrate definition "zo "of "induetion" "The initial step in any undertaking " I. however, think Fichard is a 1 so using "induction" here as an inferential. process, relying on people to infer or induce, "danger"us 1y" (for Clarence and subsequent others). George rather than Gloucester from the "G" of his prophecy" In this case "induction" is more commensurate with definition $7 . \mathrm{b} "$ "An act or instance of induction" the result of this: a conclusion derived from indution formerly used in the wider" sense of 'inferenes" " This definition originates from the midwifteenth century ("c.1440") and is thus viable for shakespeares use. 
George (Duke of Clarence) and as we know from later in the plays Qloucester" was "of Edward's heirs the murderer". Labelling his various prophecies as "inductions dangerous" Fichard also sems to be aware that such induction is notoriously unreliables even "dengerous" "if the wrong conclusion is drawn, whichy as he expects, it. is " How, thoughy can Fichard be so confident the "G" will be taken as George? The answer lies in a combination of clarences history and Fichard's duplicity. The memory of clarence's earlier defection to the lancaster faction fportrayed in $F$ Henry $W$ and recalled here by clarence's murderers" "Thou didst receive the sacrament to fight / In quarrel of the house of Lancaster" - Fichard III, Second Murderer, I.iv "206207), though ostensibly forgiven by Edwardy mus 5ti.1 exerejse some doubt as to clarence's whole-heared loyalty. while Fichard's ingratiating "external appearances" as the trustworthy and faithful brother and servant of the king wold: on the contrarys remove any doubt as regards his loyalty" Fichard's plan" then" is minutely calculated and firmly grounded to exploit the inductive process.

The second point of interest in Fichard's speech is his statement that if Edward is as "true and just" as he (Fichard) is "subtles false" and treacherous" then the plan is bound to proceed as he wants. The implication here for us is that the characteristics of truth and justicen and the processes they may be seem to signify (historical and 1 egal respectively), ape open to manipulation and exploitation" and can be subverted by subtlety and treachery. The "truth" 
can thus be controlled or created (by Richard) through an awareness that the historian can only report, and the laywer only accuse, what is "known" or seen, that is: "external appearances": the sought after" "inner"truth" can only be suspected, suggested, or , in shakespeare's cases invented.

This fact is made clear in relation to the circumstances surpounding clarence's murder. In contrast to the account given by More (cited above) where Fichard is implicitiy inked to the crime through a combination of "wise" thought and the suggestive "hasty" execution: Shakespeare as drametic/poetic "historian" can invent action and situations to correspond with the "inner" invisible truth" More suspects or suggests. In Richard IIT" the murder is ordered by Richard in an underhand and secretive fashion, divored from any sense of legal propriety. We see, in the opening scene of the play (I.i.340f), the murderers collecting a specially prepared "warrant" (a legal document drawn for an i.1.1egal use) from Richard to gan admittance to clarence's prison, and hear Fichard's last orders" "But, sirs, be sudden in the execution, / Withal obdurate: do not hear him plead" (11.346$347)$.

In the actual murder scene (I i. iv), clarence, imprisoned in the Tower as a consequence of the dubious prophecy and facing his murderers, can only lament and decry this prejudicial state of affairs in a spech replete with legal terminology:

Are you drawn forth among a world of men 
To slay the innocent? What is my offence?

Where is the evidence that doth accuse me?

What lawrul quest have given their verdict up

Unto the frowning judge? or who pronounced

The bitter sentence of poor clarence' death

Before I be convict by course of law?

To threaten me with death is most unlawtul.

$$
\text { (I. i. . 184-191, my emphesis) }
$$

The legal procedure which clarence's speech outlines as his entitlement is the complete antithesis of the justiciary role that Fichard has taken upon himself. Richard has circumvented human kinship and societal (legal) ties and constraints to effect his own expedient ends. Edward's virtues of truth and justice have been exploited to bring about the imprisonment of Clarence, and now Fichard's mercenary justice, signified by his hired murderers, is about to be applied in the face of pleas of innocence and calls for a lawful trial" In terms of the wider context of the play, this scene depicts the breakdown of legal process and procedure due to Richard's Machiavellian inclinations, and this sets the pattern for Fichard's continuing disregard for proper legal procedures. Dperating within his own personal parameters, he is effectively a law unto himselfy driven by his "inner, invisible" desire for the crown which he manipulates his "external appearances" to serve. Questions of innocence or guilt, "evidence" and "course of law", as they are popularly defined, are no longer valid.

This scenario is illustrated in our second case, in 
which Richard charges Hastings with treason. Here the accounts in More's History and Shakespeare's Richard III exhibit many similarities (outside of their differing modes of presentetion) in their respective sequences of events. Clearly the History, in whichever Chronicle Shakespeare was using, is the main source for these scenes in Richard $I T I$.

The events recorded by More and dramatised in Richard Ix 2 leading up to Hastings being charged with treason are in accordance with the conclusion of legal historian J.G. Be11amy, who states that:

Only in the reign of Fichard III was there what appears to have been gross abuse of the law. In 1483 there does not seem to have been any legal process at all, proper or improper, before the execution of William Lord Hastings $\geq 9$

In both the History and the play the execution is deemed necessary and expedient by Richard due to Hastings's antagonism to the idea of Richard assuming the throne. Sounded out on the matter by the double agent catesby, Hastings is unequivocally against the idea. More reports that Catesby, sent by Richard "to test, with some words cast out afar off whether he could think it possible to win the Lord Hastings unto their party," found Hastings "so steadfast and heard him speak so terrible words that he [Catesby] durst no

za.G. Eellamy, The Law of Treason in England in the Later widdle Ages" pg 215. 
further proceed."so Shakespeare, following this order of events" turns the "terrible words" of Hastings into the emphatic denial:

I'1 have this crown of mine cut from my shoulders Before I'll see the crown so foul misplaced.

$$
\text { (III. i.i. } 43-44 \text { ) }
$$

Even after Catesby gives the news of Richard's gory bribe and gesture of friendship - unprecedented in the History - of the murder of Hastings's Sworn enemies Rivers, Grey, and Vaughan, " $x$ Hastings remains "steadfast":

$$
\begin{aligned}
& \text { But that I' } 11 \text { give my voice on Fichard's side } \\
& \text { To bar my master's heirs in true descent - } \\
& \text { God knows I will not do it. to the death! }
\end{aligned}
$$$$
\text { ( III. i. . . 5 - }-55 \text { ) }
$$

Hastings, then, through his loyalty to the recently deceased Edward IV and now his son and "rightful" heir" prince Edward, is an awkward encumbrance to fichard's plans and plots "Some means to remove him must therefore be devised. It is at this moment that Fichard's intentions once more collide with the constraints of legal process: and we see what Bellamy describes as a "gross abuse of the law."

\footnotetext{
momore, pg 68.

w Concerning this act Eellamy, The Law of Treason in England in the Later Widdle Ages, pg 215. states "there seems to have been very little [legal process, proper or improper] before the deaths of Earl Fivers, Sir Fichard Grey, Sir Thomas Vaughan." Likewise More's History, Pg 79, records their deaths as "lawless" and "without judgement, process, or manner of order."
} 
The abuse of the law fichard carries out is a masterful achievement in that while he uses no legal process per ses it i.s posible to see the legal framework around which he buids his charge of treason. In so doing Richard seems to be exploiting those "limitations and potential falsifications involved in the process of making visible an invisible truth" most notably: he exploits the inherent vagaries of the law of treason in its inclusion of "imagining and compassing the death of the king "his queen or the royal heir" in an effort to establish Hastings's guilt. of course Fichard, at this point of proceedings" is not yet king but rather the young king Edward V's Lord Protector. He could, however: apply the law of treason to himself through his royal. blood. Also, Edward $v$ s coronation has not yet occurred, thus alowing fichard a little more room to move as a king-substitute. The manifestation of this "imagining and compassing" on which Fichard establishes Hastings guilt is the use of treasonous words: a form of treason to which Fichard, early in Bichard TII, has already alluded when admonishing Brackenbury" "We speak no treason. man" (I.i.90). In this sort of treason, spoken words are held to be the overt evidence for, or expression of, covert treasonous "imaginings" or intentions"

The case of Hastings's treasonous words which Richard constructs, however, is contrived and highly tenuous. The History reporte that Fichard, rewentering the council room after a brief absence, enquires (ominously) to those present:

"What are they worthy to have that compass and plot the 
destruction of me, bejng so near of blood unto the king: and Frotector of his royal person and his realm?uz

Likewise in Pichard ITI, Fichard seses to know what is an appropriate punisment for those "That do conspire my death with devilish plots / of damned witcheraft" (III.iv.59-60). As evidence of these "devilish plots" whith everyone present i. asked to "witness of their evil" (1.67), the character Fichard produces his deformed arm" "behold! mine arm / Is 1ike a blasted sapling, withered up" (11.68-69). This, in both More's History and the play: is represented as blatantiy untrue" in the History More comments that "no man was there present but well knew that his arm was ever such since his birth."s; standing accused of this (invented) offence is "Edward"s wife" (1.70" More" "that soreeress" "pg 7o), Queen Elizabeth, and "thet harlot, strumpet Shore" (1.71, More: "that other witch" "Shore"s wife" " pg 70) " now Hastings's $\operatorname{mis} \operatorname{tres}=$

The trap is now sprung, awating Hastings's reply to seal his fate. The resemblance here between the prose history and the drama is marked. In the History Hastings answers" "Certainly" my Lord, if they have so heinously done, they be worthy heinous punishment", on which Fichard pounces:

"What!" " Thou servest me, I think, with ifs and with ands! I te11 thee: they have so done! And that, I wi.1

\footnotetext{
samore, p9 69. My emphasis.

m:More, po 70.
} 
make good on thy body, traitor" ":4

In the play, where the echoes of More's situation are obvious the interchange is as follows:

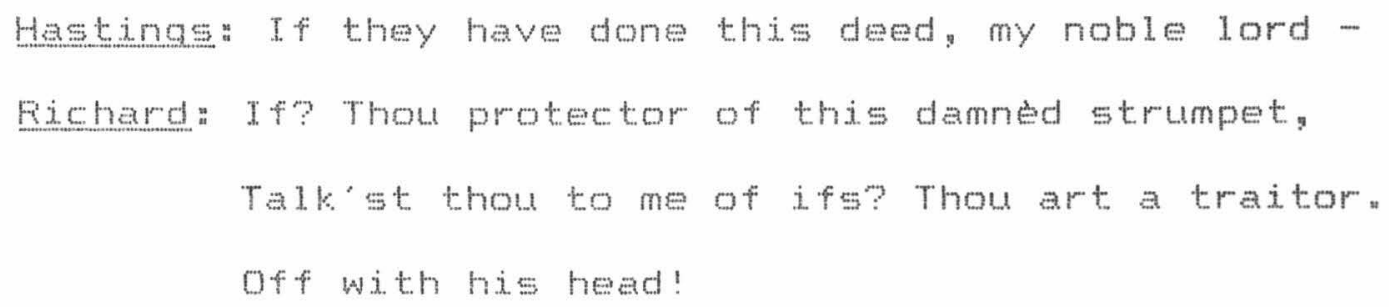$$
\text { (III. IV. } 7,7-76)
$$

One word - "If" - is enough for Fichard to induce treasonous intent in Hastings and call for his execution. Fichard, then, has seized the first convenient opportunity that arose to effect his will.

Emphassing Fichard's disregard for both the law and legal procedure, and illustrating his capacity to pervert judiejal methods is the format this brief episode (twenty lines from accusation to sentence in the play a appoximately onewthird of a page in the History) seems to follow - that of a pseudo, or mock, trial. To begin. Fichard states the case in queston and identifies himself as the victim of the crime committed. He then produces his own evidence and names the perpetrators of the aforesaid offence. Finally. using Hastings's own words as proof of treasonous intent through his involvement with the perpetratorss Fichard finds Hastings guilty and sentences him to death. Fichard has thus acted not only as the victim of the crime: but also: in the subsequent

अ MOHE: pol 70 
"trial" as both accuser and judge. The other lords and nobles (including Hastings until his fatal "if") there gathered view proceedings: and can thus be seen as representing a jury. Significantly, after being consulted as to what the perpetratore of the alledged "plots" deserve. they remain silent throughout, powerless to intervene in Fichard's dominating and domineering performance. What Fichard wants he achieves, by fair means or foul. Lastly: the extreme brevity or summary nature of the trial would also seem to be a distortion of those cases carried out in a thorough and procedurally correct fashion.

A fitting conclusion to this discussion of how legal practice and process reflects, impingesupon, and interacts with historiographic practice and process comes by way of the play's preamble - not found in the History - to the scene of Fichard's mock trial of Hastings. Here we return to the theme of the undiscoverable nature of "inner" invisible truth" through the evaluation of "external appearances" " the essential and unenviable task of the historian/ nistoriographer and lawyer alike. Having met to "determine of the coronation" (III "iv.2) of young Frince Edward" the nobles there gathered cannot decide finally until they know "the Lord Frotector's [Fichard's] mind" (1.7) concerning the matter. Talk then turns to the problem of knowing someone's "mind" or "heart" ("inner" invisible truth") from their "face" ("external appearances"). Buckingham asks who is the most "inward" (1.8) with Fichard! the Eishop of Ely thinks Buckingham is such a man and should therefore "soonest know 
his mind" (1.9). Buckingham's reply will be immediately recognisable in relation to our discussion"

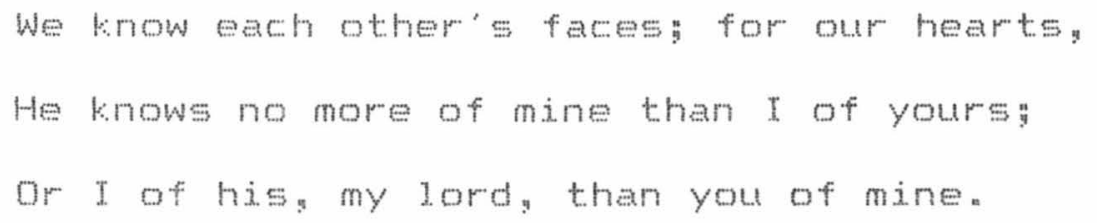

This, then, is the definitive stetementa while it is possible to know someone"s "face" it is impossible to know someone's "heart" 3

Having established this, the scene then illustrates that those attempts to know someone"s "heart" (as in the courtroom or a work of historiography, for exampley, be it by More's "conjectures" or Maus"s "induction" "are consequently and inevitably prone to error and/or manipulation. After a brief appearance by Fichard: Hastings performs his own induction as to Fichard's "heart"

His grace looks cheerfully and smooth this morning:

There"s some conceit or other likes him well.

When that he bids good morrow with such spirit.

I think there's never a man in Christendom

Can lesser hide his love or hate than he"

For by his face straight shall you know his heart.

ssignificantly, Richard himself expresses similar sentiments in his remark to Frince Edward" "Nor more can you distinguish of a man / Than of his outward show: which, God He knows, / Seldom or never jumpeth with the heart" (III.i.9-11). To "God" we may also add the play's audience who also "know" through their admission to Fichard"s "heart" in soliloquy" 
of this statement Derby enquires, "What of his heart perceive you in his face / By any livelihood he showed today?" (11.5455), to which Hastings confidently replies"

Marry, that with no man here he is offended;

For were he, he had shown it in his looks.

(III. i. . 56-57)

This "truth" that Hastings discovers could not be more untrues as subsequent events are about to reveal.

The above scene, then, seems to suggest an awareness that the discovery of the "truth" or "heart" of a matter from its "face" or surface appearance. be it in a legal, historiographical or, as in this scene, political context, is dependent upon such unreliable practices as induction and/or speculation. This unreliability will mean that wrong conclusions, or wrong "truths" " may be "discovered" " Clarence"s misinterpretation of the "G" prophecy, or Hastings's misjudgement of Richard's "face" for example. More's prose historiography, and Shakespeare's dramatic verse historiography, therefore, are themselves only "part of the truth, an evidence of things not seen, or not entirely seen"se due to their" "inner, invisible", and consequentiy inscrutable, nature. Thus the "truth" itself "exceeds public methods of representation", 37 be they historiographical

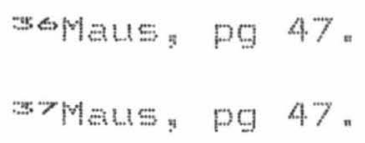


(textual or dramatic)" or legal. The play, however: as well. as suggesting this fact as regards the discovery and subsequent representation of the "truth" "aso seems to put forward the hypothesis that the "truth will out", less to be discovered than "known" "with this "knowledge" (as opposed to More's "conjectures") being the basis of the dramatic production. Within this scenario the "truth" as prince Edward asserts, will. "live from age to age." Even to the general all-ending day" "se if not as discovered ("registered") "truth" then as unsubstantiated "knowledge" .

sagee above. pp $64-66$, for a full discussion of the Prince's assertion regarding the "truth" 
The Dismutive influence of Foetry

The anonymous history play The Raigne of King Edward the Third (Edward TII) was written some time between 1589 and $1592, x$ and $\dot{x}$ s thus contemporaneous with shakespeare's early history plays " one episode of the play - the Edward III Countess of Salisbury scenes of Act Two, in which the action deviates from the mistorical plane - is of particular relevance to my diseussion of Fenaissance historiography and its grappling with the concept of historical "truth" "This episode deviates from the historical plane alongside a deviation in source from Froissart's Chronicle, the play's mistoriographical source, to the romance of William Fainter's "Forty sixth Nouell" in The Palace of Pleasure." This is not

1Fred Lapides (ed.), The Raigne of King Edward the Third (New York" Garland Publishing: Inc." 1980)" pg 37 . All subsequent references to the play are taken from this edition.

while it is not a concern heres it is worth noting that the question of authorship regarding Edward $I I Y$, and the possible involvement of shakespeare therein, has been a highly contentious and much debated issue. In his introductory discussion of the authorship of the play, Metz identifies four differing critical opinions" those who deny entirely any participation by shakespeare: those who see Shakespeare as a reviser, in Edward III, of an earlier drama which may have been two separate plays! those who elaim shakespeare's part-authorship of the play: and those who naintain shakespeare is the sole author of the play. For an elaboration of these views see G. Harold Metz: Sources of Four Plays Ascribed to Shakespeare (Columbian University of Missouri Fress, 1989), pp 6-20. Also Lapides, pp $3-31$.

Metz, pq 31. 
to say that the episode in question is absent in Froissart; it appears: but is merely sketched when compared with the elaborate encounter Feinter describes in his romance narrative; and which the play more closely follows.

In his Chronicie, Froissart describes the encounter between Edward III and the Countess of Salisbury as taking place over just one day and night with Edward firstiy declaring his love for the Countess:

the swete behavyng the perfyt wysedom, the good grace. noblenes, and excel. lent beauty that I se in you, hath 50 sore surprised my hert, thet I can nat but love you and without your love i am but deed"4

In reply, the countess rebukes Edward for his attempt to "dyshonour" both herself and "my lord" my husbande" who has previously been of "so gode servyee" to the king. The encounter concludes the following day with Edward: suitably admonished by the Countess: departing her castie to recommence his batties:

Therwith the kyng departed all abasshed: and soo folowed

4From The Chronicle of Froiseart, vol. I (translated by Sir John Bourchier, Lord Berners, 1523-1525), reprinted in Metz. pg b6. Jean Froissert (c.137.w.1410), a French chronicler and poet; compiled his chronicle in the second half of the fourtenth century. From 13b1-136b Frojssart resided in England, serving at the English court lof Edward III) as secretary to Queen Fhilippas and later as court chronicler. He briefly visited England again in 1395. Froissart a Chronicle would have been available to the Elwar $2 I T$ playwight through Berners's translation. For further information see Metz. pp $20-40$. 
the Scottes ty 1 he came to the cyte of Berwyke "

Fainter expands this brief encounter into a more lengthy love-suit (comprising the whole of the 46th novelia), similar to that in the play, conducted through love letters and the reluctant aid of the countess's father. among others. The most notable and significant differences between Fainter's version of Edward's love-suit and that which we find in Edward III are those of the location and the conclusion. The majority of Fainter's action takes place in London, not in the countess of Salisbury's castle as in the play and Fainter's tale ends with the marriage of Edward and the Countess: made possible through the death of the Earl of Salisbury: the Countess's husband. No mention is made of the historical Queen Fhillipa, Edward's wife, other than in an authorial disclaimer prefacing the novella, which advertises its fictionalitity:

And that the said Edwarde when hee saw that hee could not by loue and other perswasions attaine the countesse but by force, married the same countesse; which is altogether vntrue, for that folydore [Vergil] and other aum thoms do remember but one wife that hee had, which was the sayde vertuous philip."

Through Queen Phillipa's presence in Edward $T I I$, then,

\footnotetext{
sFroissart, in Metz: pg 67.

GFrom "The Countess of Salesburie" "in William Painter"s The Palace of Pleasure (1575). reprinted in Metz. pg 109.

A11 further references are taken from this edition.
} 
Edward's pursute of the countess is made all the more immora ." One further difference between fainter and Edward II is the change in focus from amorous prose to poetry. In the Pasce of plessure Edward conducts his loversuit via love letters rather than love poems: and: as we shall see: the language of the dramatic character Edward is replete with poetic terminology.

Elwaro IIXS emphasis on poetry. then. in an episode which acts as a deviation from the historical component of the play: seems to give voice to the growing late-Fenaissance distinction between the written media of history and poetry, and to draw attention to the "disruptive" influence poetry could exert on both historiographical process and representation, and thus on historical "truth" "This growing distinction between historiography and poetry was a result of the development through the sixteenth and seventeenth centuries of history as an autonomous discipline. As Phylids Fackin destribes:

at the beginning of the Eixteenth century: English

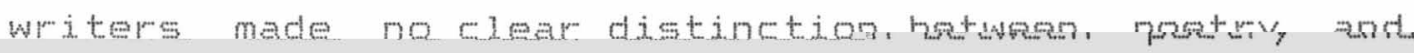
history: either of which could be written in prose or verse, both of which freely mingled fact and legend, event and interpretations and endowed characters from the past with the customs and manners of the present. By

'Likewise in Froissarts account of the countess of Salisbury episode where no mention is made of either Queen Fhilipa, or king Edward's prospective adultery - it is the Countess who will be violating her marriage vows if she suctumbs to Edward's advances. 
the seventeenth century, all this had changed: history had become an autonomous discipline with its own purposes and methods, clearly distinct from myth and 1.iterature: and accountable to different formal requirements and different truth criterian

The genre of the Renaissance nistory play, by way of its unique combination of both poetry and historiography, occupies a Janus-1ike position in this historical development. In relation to Edward $I X I_{*}$ we can see the play looking back and incorporating those aspects Rackin identifies as typical of the early sixteenth century, while also looking forward, in terms of development, to plays sueh as Shavespeare's Henry $y$ with its heightened historical thought and consciousness (discussed in the second part of this Chapter). The play thus supports Holderness's argument that the "English Fenaissance history play. " represents inevitably a transitional period in which different ideas of history competed for dominanee."

Rackin's points, quoted above, also suggest a reason for

Brackin, po 19. Kamps, pg 12, however" finds Rackin's description as "much tidier" than the "thoroughly eclectic [nistoriographie] practice" of the time, and as not reflecting the "grave contradictions in theory and method" that were simultaneously embraced. He also does not see the distinction between history and poetry as happening until the eighteenth entury, when "history and the philosophy of history came to be viewed as respectable, well-defined disciplines distinct in aim, content, and method, from poetry," $\mathrm{pg} 12$.

-Holderness, Shakespeare Recycled, pg 8. See my Introduction, pp 16-19, for further discussion of the "transitional" nature of the genre. 
the perception of poetry as having a disruptive influencen in that poetry lost its assomiation with the truth or with historical truth at least, as historiography moved towards autonomy. Poetic truth became seen increasingly as imaginative truth, an ideal version of the world with a general or universal focus. It was therefore a kind of truth that was at odds with the historian's more realist, localised and "factual" equivalent. As Sir Fhilip Sidney states in his Apology for Poetry (1595) when asserting the superiority of the poet over the historian:

\begin{abstract}
the historian. " is so tied" not to what should be but to what is, to the particular truth of things and not to the general reason of things, that his example draweth no necessary consequence, and therefore a less fruitful. doctrine " 10
\end{abstract}

Despite humanism's counsel that historiography should provide a guide for moral and political behaviour, history and poetry increasingly "dealt with different things, dealt with them in different ways, and addressed themselves to different ends."1. The Edward III -- Countess of Salisbury episode of Edward III which represents a distinction between poetry and history, and the dismuption of historical "truth" by poetry, contrasts with the rest of the play in both structure and theme. These contrasts suggest that the "historical"

\footnotetext{
xogir Fhilip Sidney (ed. Geoffrey Shepherd), An Apology for Foetry (Manchester" Manchester University Press, 1980), pg $107,1,4-8$.

1. Baker; pg 82.
} 
component of the play deals with external, political. public: military and predominantly male matters" while the "poetic" component (Act Two primarily) deals with internal, domestit, private, and emotional matters between the sexes.

From the initial sene of Edward $T I T$ we are firmly situated in the domain of history and the historiographic genre of the English History Flay " In the English Eourt of Edward III, the king and his nobles discuss Edwards Iineal claim, transmitted through his mother, to the French throne: this discussion (1ike the similar scene in Henry $y$ ) historically justifies his intention to gaing by force if necessary, his "right" in France "News arrives, however, of a Scottish invasion in the northern borders of England and of the capture of the countess of salisbury and her castle by the Scots. Before the French campagn can proceed this more immediate threat must be quashed, and the second scene of the play recounts Edward:s suppression of the scots and the resultant freeing of the Countess. The serne ends with Edwar's acoptance of the Countess's invitation to "stay a while with mee" (I.i.j. 1. "Eo)"

This aceptance marks the structural transition within the play from the domain of history (Act one) to that of poetry (Act Two), as we turn from the affairs of state to the affairs of Edward's heart. As Edward suceumbs to his desire for the countess: the outside historical world seems suspended. The king becomes preoceupied with the elaborate expression of his emotions in written verse and such 
ornamented speech as: "Ah what a world of descant makes my soule, / Vpon this voluntarie ground of loue" (II.i., 1.456457). Act Two concludes with Edward realising the faul of his poetic and potentially adulterous sidetrack - "I am awaked from this idle dream" (IIni.s. 1.994) - to return once more to the province of (masculine) historical, political and public activity. Immediately, he gathers his forces and makes arrangements for the invasion of France: which comprises the subsequent action of the play"

Structurally, then, the Edward III - Countess of Salisbury episode is interpolated between preparations for the French campaign and the actual invasion of France. The episode can therefore, I think, be seen as a dismuption, or even, at worst, a potentialiy devastating threat to the chronological or Iinear progression of historical event which here, ostensibly at least, equates to historical truth. For an Elizabethan audience, the title and first aet of Edward II would al1 seem to point towards an "historical" representation of this famous king's conquest of France. Especially when one considers the popular reputation of King Edward II in the Fenaissance; captured in Thomas Heywood's Apology for Actors:

that amous [sic] King Edward the third: foraging France: taking so great a king captive in his owne country, quartering the English Lyons with the French Flower- 
The second act, however, sees the historical representation hi-jacked by the poetically-orientated considerations of Edward's desire for the Countess. Structurally and symbolically, then, it would appear that the play, in this episode, takes us from the realm of history and historical truth to that of poetry and poetic truth, withs in Baker's words, its dealings with "different things." " in different ways, and addressed. " to different ends "

This leads us to the thematic contrasts between the Edward II -- Countess of Salisbury episode and the surmounding action of the play as the preceding and subsequent militaristic and nationalistic themes are momentarily suspended and superseded by themes and considerations of romance.

Our first thematic differentiation comes at the close of Act one with the Countess's invitation to Edward to repair to her castle. In this invitation the countess stresses the fact that the external appearance of her castle in no way indicates the internal comfort and beaty of the residence:

Our house my liege is like a country swaine, Whose habit rude, and manners blunt and playne, Fresageth nought, yet inly beatified, With bounties riches" and faire hidden pride:

12Thomas Heywood, An Apology for Actors (1612) (New York: Johnson Reprint Corporation, 1972), Book I, B4r." 


\begin{abstract}
These ragged walles no testimonie are" What is within, but like a cloak doth hide? From weathers waste: the under garnisht pride.
\end{abstract}

$$
\text { (I. i. , } 11.314-317=-326-328)
$$

This: then, seems to point towards a change in focus as regards the truth - e change in focus, I believe, from historical truth which deals with external and "public" matters, to that of poetic truth which deals with internal and "private" matters" The action of the play prior and subsequent to the Edward - Countess episodes that which constitutes the historical component. operates very much on the level of political affairs as events revolve around the respective courts of England and France and the French battlefields. This is the historical truth - the conquest of France by Edward III and his son, Frince Edwardy the Black Prince -... that the play presents. The Edward - Countess episode: however, moves away from the external and public worle as it deals with the internal private emotions of Edward. Onee he steps inside the Countess's castle he passes from the outer domain of history to the inner domain of potery.

The poetic truth here is that of emotion sines: for Edward, poetic truth stems from the heart:

o that a man might hold the hartes close book: And whoke the lauish tongue when it doth vtter The breath of falshood not carectred there. 
Anything spoken (or written) which does not originate from or equate to the contents of, the heart is therefore deemed false. For example, when Edward commands Lodowick to compose a poem expressing his love for the Countess, he wants nothing but true and affecting emotions and sentiments to be recorded:

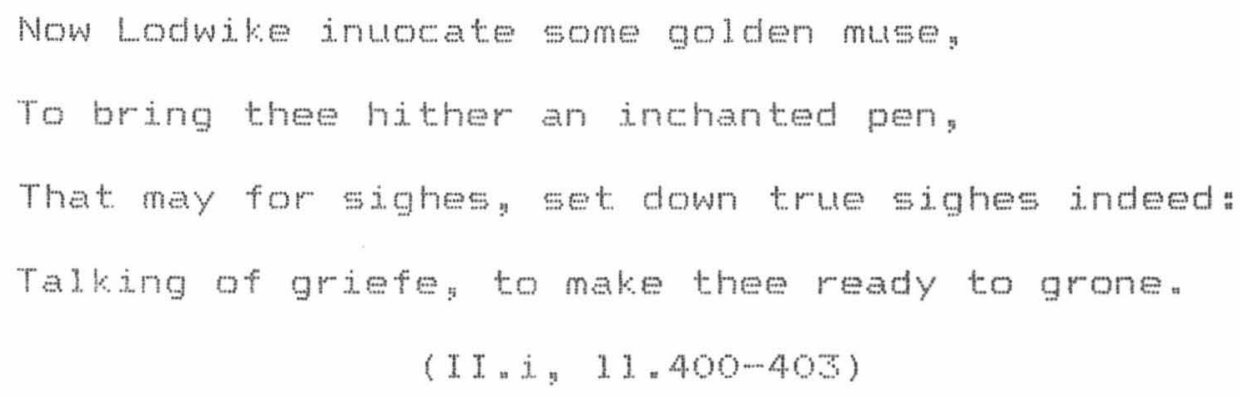

The last instruction here to Lodowick regarding "griefe" would appear to be the poetic equivalent of the exemplary use of historical truth where history is recited to incite similar actions and/or reactions in the hearer or reader" Here, Lodowick's poem is required by Edward to incite similar "griefe" in the hearer". The truth to be extracted, however" is emotional rather than political.

Another example of poetic truth being juxtaposed with, and as a result contrasted to or differentiated from, historical truth comes from the second scene of the episode under discussion. Here we find Derby and Audley seeking an audience with king Edward to report the news from the outside, historifal, world that "the Emperour / Hath yeelded to his highnes friendly ayd" (II,i., 11.802-80s). Upon the king's appearance it is obvious he is firmly entrenched in 
his own world of emotions characterised by his obsession for the Countess. When he is told Derby and Audley's news. Edward is thoroughly dismissives and he shows the preoccupation of his heart and mind with the countess by speaking her titie instead of the Emperor's:

Edward" Darby lle looke von the Countesse mind anone. Derby: The Countesse mind my liege[?].

Edward: I meane the Emperour" Ieaue me alone.

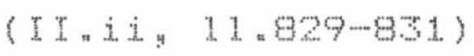

This exchange picks up from Edward's earlier statement. quoted above, that only that which stems from "the hartes Elose book" is deemed to be the (poetic) truth. For Edward to say "Emperor" would be "The breath of falshood" within his heart is written "Countess" not "Emperor" " therefore "Countess" isy at this point in timey the truth. Edward himself concludes the same when Derby and Audley have left him:

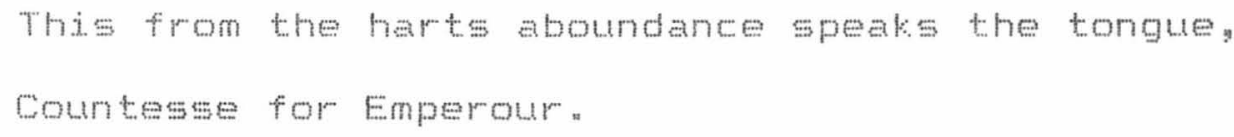

Another thematic differentiation in the Edward Countess episode is the change. distortion which military language and symbols (which I take to represent the outer" nistorical" domain) undergo as they are spoken of or used in the "poetic" and emotional context. A good example of this occurs in the versewcomposing scene between Edward and Lodowitk. Just as Edward is commenting on 
Lodowick's inability to capture vicariously in verse the true sentiments of a lover, the countess enters upon the stage. To cover for his activity and the topic of conversation, Edward, in a pointedly comic moment. quickly changes tack to an ostentatious display of military tacticianship:

But soft here comes the treasurer of my spirit.

Lodwick thou knowst not how to draw a batte11,

These wings, these flankars, and these squadrons,

Argue in thee defective discipline.

Thou shouldest have placed this here, this other here.

$$
\text { (II. i. } 11.519-523)
$$

What we see happening here is Edward resorting to his historical vocation and the vocabulary of king and soldier to provide a facade for his current vocation of lovesick poet. The historical truth, then, has become subservient to the poetic truth. This idea of an external facade hiding some internal truth seems to be a charateristic of the poetic domain inhabited by the Countess. In her earlier invitation to Edward, as mentioned above" the Countess stressed the fact that her castle's outer appearance belied its interior, and now we see that the military role Edward assumes as cover" one which would be the truth outside the castleg is here merely an expedient device to conceal his own inner state. Edward's use of military terminology has thus been appropriated from its proper historical or historiographical context to act as a convenient facade for his current "poetie" inelinations. 
simpler oteurenees of this perversion of military language and images through their juxtaposition with, or placement in. the poetic context are elsewhere visible in Edward's speech. A representative example is when Edward voices his intention to use warwick the Countess's father: to further his love-sut. His intention is couched in the imagery of battle

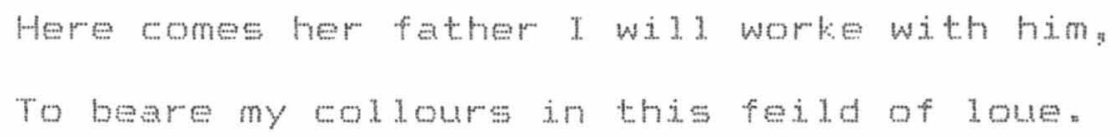

Battle images - "collours", "feild" - are here appropriated for poetic rather than military usage in the manner of Iiterary conventions of "love as war" or "soldier turned lover:"

The physical attributes of the soldier are also subject to appropriation in Edward's temporary residence in the poetic domain. Upon hearing the distant beating of a drum, which indicates marching soldiers ${ }^{2}$ he wishes the skin or "parthment" of the offending drum to be stripped off and used for writing verse:

Go breake the thundring parchment bottome out. And I will teach it to conduct sweet lynes, Unto the bosome of a heauenly Nymph, For I will use it as my writing paper. (II. i. . 11.845-848)

The military drum, which will later herald Edward's march 
into France: is here requisitioned for the purposes of poetic expression. It will be seen, then, that nothing connected with Edward's historical role as conqueror of France. be it linguistic or symbolic: retains in his mind its "true" identity" use" or purpose while within the confines of the Countess"s castle. History is momentarily overwhelmed or disfupted by poetry.

In summary: the Edward II -. Countess of salisbury episode seems to encapsulate the growing Fenaissance opposition and tension between the differing agendas of history and poetry: especially with regard to the presentation of the "truth". Structural1y the episode interrupts the historieal progression of the plays while thematically it turns from the affairs of state (history) to affairs of the heart (poetry).

It is interesting to note that this same antipathy between history and poetry can be seen in miniature in the sceme of Henry $V^{\prime}$ s woing of the French Frincess katherine at the close of shakespeare's Henry W (V.ii) "Here, however. Henry declares his inability as a "soldier" to plead a "loveguit" (Vni.i.99,101), x. Furthermore, when it comes to "verses" he has "neither words nor" measure" (1,132,134). Henry, onee removed from the political and military context where his whetorical sti1. f flourished" articulates a similar distrust

1.4111 am Shakespeare, Hemry Fenguin Books Lto" 1988. All subsequent quotes are taken from this edition. 
of poetry or "rhyme" (1.155) to bear the truth. Henry's position here is that those who use "rhyme" for romantic ends, in opposition to those who, like himselfy speak "plain $/$ goldier" (11.148-149) and "true English" (1.219), are not to be trusted:

For these fellows of infinite tongue, that can rhyme themselves into ladies' favours, they do always reason themselves out again. What! A speaker is but a prater, a rhyme is but a bal1ad.

$$
(V . i i=154-158)
$$

Quite clearly Henry is being represented as a man of action (history) rather than one of ination (poetry). so much so thet Henry's foray into potic concerns occurs after his historical famen that is, when victory over the french at Agincourt has been realised, not before as in the case of Edward III.

\section{Prince Edward and History}

Feturning to Edward $I Y$, subsequent to the Edward III Countess of salisbury episode, we find the agenda of history and its version of historical truth reinstated with the English invasion of France. At the forefront of the charge is Edward III's son Prince Edward, the Elack Frinee, who is characterised by the text as being responsible for the making: or writing: of history. The Frince is thus 5 et against his father and his earider efforts at composing a lovewpom. To bring about this contrast the play uses the 
image of the "pen" "The poet's pen. as used by Lodowick at Edward's behest, is associated with a supernatural source the previously quoted "golden Muse" and "inchanted pen" -II. i. 1.400,401), while the poetry produced has an overwhelming, even hypnotic , effect:

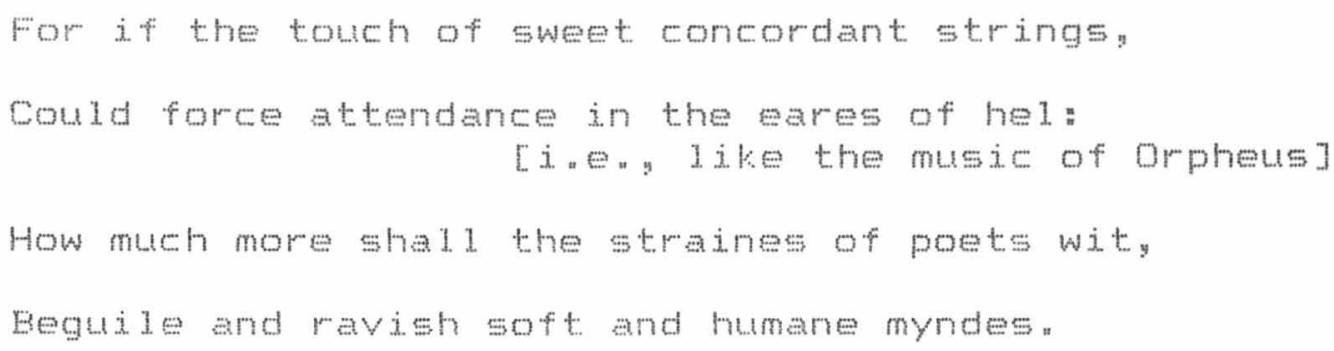

The last line here points towards the power of poetry and the poet: and seeme to persude them to some morally adverse action or behaviour" This is "of course" the very intention of Edward" to use bodowick, who has a "perswasiue spirite" to "beguile and ravish" the Countess's mind (and body) into complicity with his adulterous desire. The text (itself, ironically: poetry) therefore associates the pen of the poet with incitement or persuasion to improper and unworthy acts.

The writing of history, on the other hand: is done by tools such as Frince Edward's lance: which the text equates with the pen of the historian. Before the frince's first batte and initiation into the ways of warfares Audley presents him with a lance: and instructs him to use it as a "brasen pen" to write. through performance. those "valiant 
deeds" which wi11 become history for succeeding ages"14

Edward Fiantagenet prince of Wales:

Receive this lance into thy manly hand,

Vse it in fashion of a brasen pen.

To draw forth bloudie stratagems in France.

And print thy valiant deeds in honors booke.

(III. i.i.i., $11,1462-1466)$

This suggestion that Prince Edward is creating (writing) history as he proceeds through france is fully realised later. at the end of the play: when he expresses the wish that all the trials and tribulations he has thus far undergone were now:

" " redoubled twentie fold"

So that hereafter ages when they reade

The peinfull traffike of my tender youth

Might thereby be inflamed with such resolve,

As not the termitories of France alone,

But likewise Spain, Turkie, and what countries els

That iustly would prouoke faire Englands ire,

Might at their presence tremble and retire.

$(v, i, 11,2480-1487)$

The historical deeds performed with the lance are

\footnotetext{
1.4The image here of history being written with a "brasen" pen reflects sir Philip sidney"s juxtaposition, in his Apology, of the worlds of "Nature" and "poetry" "Her [Nature"s] world is brazen. the poets only deliver a golden" (Sidney, ed. Shepherd, pg 100). The natural (historical) world, then, is "bress" to the world of poetry's "gold".
} 
automatically transferred to "honors booke" for the edificetion of future generations. This " therefore" is the twuth the historiographical quest must pursue -.. the recounting of glorious deeds as examples and precedents for the behaviour of succeding generations -... rather than the poets truth of enchantment and persuasion.

Despite the play's own use of dramatic versey it uses this distinction or dichotomy to validate the action preteding and following the Edward - Countess episode as historical "truth" "Using the popular reputation of Edward II, derived predominantly from the chronicles and expressed in Heywood's praise of "that [f]amous king Edward the third" quoted aboven the dramatst could rely on his audience to recognise and thus:

substantiate the authenticity of what was presented on the stage " The names of the illustrious personsy their good and bad deeds: the way they lived and died" the places associated with their actions were there, clear and recognisebles and their function was to convince the audience that they were witnessing the true facts of history. $1=$

Stepping as it does out of "history" and into the realm of romance: the Edward - Countess episode can be read as an example of what Holderness describes as "comic history"

[Comic History] provides a space of freedom from events

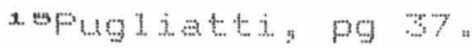


from the necessity of a complete history: thus a historical character can be liberated from his historical destiny [eg " Edward as conqueror of France]. can play roles not dictated to him by the written authority of history [eg. Edward as lovesick poet]. 1.

The corollary of this is that the "space of freedom" in question cannot be cessified as historiography.

The Use of History in Henry u

Frince Edward's hope that "hereafter ages" would upon reading his history (his story), be "inflamed with such resolve" is realised in the opening scenes of Shakespeare's Henry W... the last play in his second tetralogy of English history plays" Here. the histomical conquest of France by Edward II and Prinese Edwardy the Black Primen is used as an example, inspiration, and justification for Henry to muster his foreses and perform the same feat. Upon Henry's request for counsel from his clergy, the Arehbishop of canterbury dvises him ton

Go. my dread lord, to your great-grandsire's tombs From whom you ciang invoke his warlike spirit. And your great-uncle's. Edward the Black Prince. Who on the French ground played a tragedy, Making defeat on the full power of France. Whiles his most mighty father on a hill

roHolderness, Shakesperme Recycied "pg 1\%" 
stood smiling to behold his lion's whelp

Forage in blood of French nobility.

$$
(1 . i i=103-110)
$$

This invocation of Frince Edward's exploits on "French ground" sems to be a recollection of a seene from Edward 272 , drawn in tum from Froissart, where king Edward withdraws his forces "vnto this little hil1" (III.Vg 1.1513) while below Frince Edward is "narrowly beset, / With turning Frenchmen" (1.1524) "Three times" in the earlier play. noblemen (Artoys Demby and Audley) plead with king Edward to send urgent aid to his son, but all are denied. Edward asserts that his son must prove himself in battle and thereby earn his place in nistorynx

This is the day: ordaymed by desteny: To season his courage with those greeuous thoughts. That if he breaketh out: Nestors years on earthy Wi1. make him sauor still of this exployt.

$$
\text { (II.V, } 11.1546-1549)
$$

This is indeed what Frince Edward does: the scene concludes with the prinee's victory and consequent knighthood and a pronoumement by his father that he js now "fit heire vnto a king" (1.1605) "x The apperent recall of this episode from Edward $2 I Z$ by Canterbury in Henry $y$ then forms a dramatic

\footnotetext{
17In Froissart, Chapter EXXX (Metz, pg 80), Edward: "who was on a lytell. wyndmyl1 hill." 3 s asked for "ayde" for his son but refuses, stating that this is an oppotunity for his son to "wyme his spurres."

xafroissart, in Metz. pg 82, reports that king Edward pronouned to his son" "ye ar worthy to kepe a realm."
} 
as well as historical link between the two plays.

Following Canterbury's leady his fellow olergyman the Bishop of Ely likewise advises Henry to:

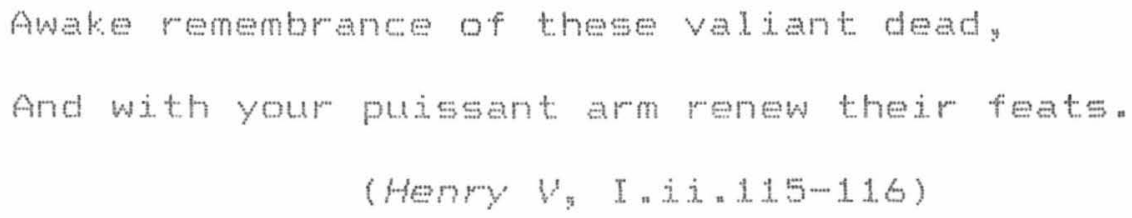

Through their respective counsels both canterbury and Ely appear to be giving expression to a humanist mode of historical thought and constiousness. firstiy in the use of history for guidane in the present, and, secondly and consequently, the implicit belief in the continuity of history - the sense that the past is rewlived in the present or: conversely, the present is a rewawaning of the past.

We can see the text at this point evidencing similar prinoiples to those implicit in Thomas Nashe's praise of historical drama in pieree Penilesse his supplicetion to the Divel2 for its copacity to resurect the past for present adification:

Nays what if I proove playes to be no extreame: but a rare exerejse of vertue? First, for the subject of them (for the most part) it is borrowed out of our English Chronicles wherein our forefethers valiant ats (that have Iine long buried in rustie brasse and worme-eaten

\footnotetext{
xhenry dates from $159 \%$. Elward 2 I from between 1589 and 1592.
} 
bookes) are revived and they themselves raised from the Grave of obliviony and brought to plead their aged Honours in open presence: than which: what can be a sharper reproofe to these degenerate effeninate dayes of wur $5 ? 20$

Nashe here makes use of historical drama to defend drama in general - identifying it as an activity or pastime that can exert a positive influence on contemporary society at large through the bringing to 1 ife of past heroes and their heroic: deeds " The specifje example Nashe supplies "comparable to Canterbury's use of Prince Edward, is that of "brave Talbot (the terror of the French)" who" on stage "in the Tragedian that represents his person, [the audience] imagine they behold him fresh bleeding." This resurrection from his "Tombe", and the replaying of his triumphs, should work as an admonishment for the current "degenerate" state of society. just as Canterbury's recollection of Frince Edwards featsy brought to life in Edwerd III should spur Henry on to perform the same .

This humanist approach to history evidenced in Nashe and in Canterbury and Ely's speeches is undermined, however, when the colergymen's counsel is seen in the context of their motivations: These" the opening of the play makes clear" are entirely selfwserving a and thus contrary to the overt

\footnotetext{
zoThomas Nashe " pieree Penilesse his Supplication to the Diwez2 (1592)" in Fonald B Mekerrow (ed")" The Works of Thomes Neshe, 5 vols. (London" Sidgwick k Jackson, Lto." 1.904), Vol. I, Pg 212.
} 
humanist agenda of honour and virtues and subsequent preservation of the common weal. Like York in 2 Henry VI who used Jack Cade and the historical name of Mortimer for his own political advancement, $2 x$ Canterbury and Ely use the history of Edward III, in conjunction with knowledge of appropriate precedents from the history of salic Law, to preserve their church's current affluent status. This is under" threat from a "bill." before the Commons which, if passed, would cause any lands bequeathed to the church to revert not to them but to state coffers, thus denying churchmen such as Canterbury and Ely a significant source of revenue:

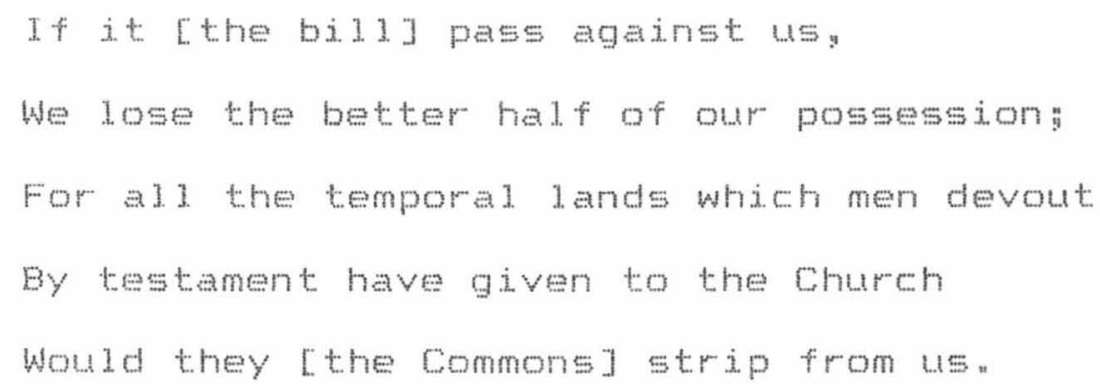

The question of Henry's claim to the French throne, then, becomes a suitable diversionary tacticy distracting Henry and the Commons's attention from the troublesome "bill" Canterbury and Ely use the facade of reinstating England's rightful ownership of France in order to protect the Church's privilege. The humanist agenda is thus put in question through its use and abuse by the clergy.

2xee Chapter 1, pp 44-45. 
This juxtaposition of a "bil1" threatening the Church"s income with Henry's claim to France is drawn from Holinshed's chronicles though in Henry Y this material is rearranged. reordered" and augmented to stress the technigues of the humanist historian behind which Canterbury and Ely hide their more self-serving intentions. Holinshed begins with an account of the bil1 in question and the effect it will haves if passed, in increasing the king's coffers while decreasing those of the chureh. some remedy by the latter is then sought:

\begin{abstract}
This bill was much noted, and more feared among the religious sort, whom suer-ie it touched verie neere, and therefore to find remedie against its they determined to assaie a11. waies to put by and overthrow this bil1: wherein they thought best to trie if they might moove the kings mood with some sharp invention, that he should not regard the importunate petitions of the commons 22
\end{abstract}

The "sharp invention" that is forthoming is the issue of Henry 5 cida to "the whole realme of France. as heire to his great grandfather bing Edward the third."zs Holinshed then proceeds with the Archbishop of canterbury"s attack "against the surmised and false fained law salike" with no further mention, unlike the play, of Edward II or the Black Prince.

\footnotetext{
artolinshed's Chronicles - Pichard $x$ I $1398-2400$ and Henry (1587), ed. F.S. Wallace and Alma Hansen (Oxford" Clarandon Press, 1917), po 9 ("Henry the Fifth" section). A1 subsequent quotes in this chapter are taken from this edition.

asHolinshed's Chronicles" ed. Wallace and Hansen. "Henry the Fitth" "pg 9.
} 
Henry"g claim in Holinshed, while derived from his greatgrandfather Edward III, rests very much on a negation of the Salic law which is alleged by the French "ever against the king of England in barme of their just titie to the crowne of France."za In Henry w however" emphasis as regards counseling Henry to pursue his claim to France rests as much upon the humanist ideal of renewing history as the refutation of Freneh salic law. Here" then. Henry is to follow in his glorious predecessors footsteps - an ideal which, in the context of the earlier discussion between canterbury and Ely. obscures the clergy's less glorious proceedings.

Another point of difference between Holinshed's Chronic le and Shakespeare's Henry w which serves to undermine or question Henry's cam further in the play, along with the humanist values by which it is presented, is the order of evente in the Church's offer of monetary aid for the French Campaign. In the Chronicle the grant of money is made in Farliament after the oration on sad. law and the statement of the legality of Henry's claim. In Henry y on the other hand, the elergy s offer of aid to Henry appears as a bribe sinee it is offered, before any discussion of the claim itself, directly to Henry (rather than in Farliament) in the manner of a back room deal"

\footnotetext{
raHolinshed's Chronicles, ed. Wallace and Hansen, "Henry the Fifth" pg 9. Holinghed later reports that after a discussion in Farliament "the bill for dissolving of religious houses was cleerelie set aside, and nothing thought on but onelie the recovering of France, according as the archbishop had mooved" pg 12 .
} 
For I have made an offer to his majesty -

" " in regard of causes now in hand.

Which I have opened to his grace at large

As touching France - to give a greater sum

Than ever at one time the clergy yet

Did to his predecessors part withal.

$$
(I . i=75-81)
$$

The knowledge of this offer thus tarnishes the following scene's call by canterbury and Ely to renew and relive the gories of the past with the taint of bribery. Where in Holinshed "the justice of Henry's Elaim to the French crown is not exactiy questioned but it is certainly doubted" $=5$ in

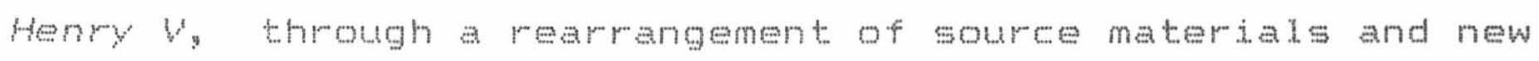
emphasis on the convenient resurrection of the past: the intentions and motivations behind Henry's claim are explicitiy questioned.

It is unclear in the play whether Henry is aware of the Clergy's motives or not. Pegarding Henry's inclination to support the Commons and the legislators putting forward the "bi11", Canterbury states"

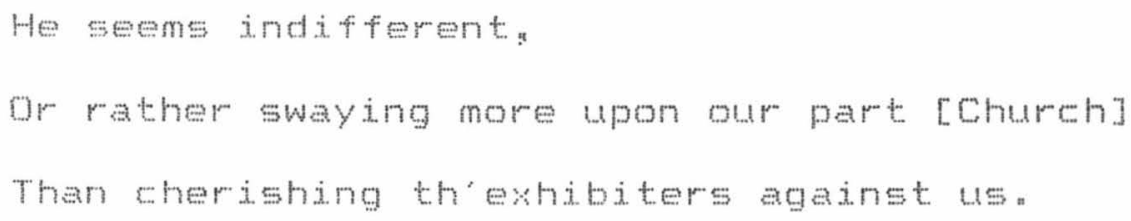

zomaham Holderness" Shakespeare's History (Dublina Gild and Macmi11an L.t. 1985), pg 1.5. 
It is possible that the call by the Chureh to awaken Henry s historical1y and legally legitimate claim to Franee may suit his own plans - the gaining of military honoury or the unity of England versus a foreign foe for example - or he may simply fall prey to canterbury and Ely. Both scenarios could be argued in a play which seems to reinforee and celebrate the ambiguous opaque nature of historical event and causation, and thus of mistoriography $=6$ Take, for example: Henry's request to canterbury"

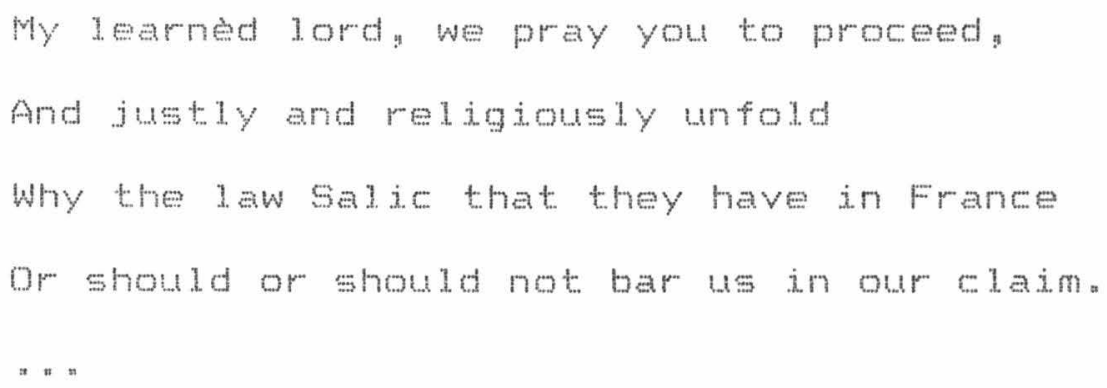

Henry here is either disereetly preparing the ground for

asfegarding this point and its relation to historieal truth, Fobert $\mathrm{C}$. Jones states" "It is as though shakespeare is determined to present 'Harry like himself' in the sense that he wij] not omit details [from his sources] that give the king 'sueh a questionable shape: at the same time that he refuses to offer us necessarily fictive actess to Henry's private plans and motives [Maus"s "inner" invisible truth"] which would give more answers to such questions 'than history can pattern. He thus abides to this extent by the given limits of nistorieal truth here and acknowledges in this sense different from the Ehorus's) that the entire Harry' Iike himself' mannot be shown (or even known):"

These bazant Deat - Fenewing the past in shakespeare's Histories (Iowa city" University of Iowa Press. 1991). pg 135 
Ganterbury to advise him that his claim to France is superficially justified and legitimate, stating that he will "believe" and act upon what he hears" or he is expressing an entirely honest call that canterbury should tell him the truth. as befits a corgyman. In both cases Henry makes it wear that the responsibility for the decision, and therefore its consequences" rests with the clergy rather than with himself. The fact that we know the hidden motives of Canterbury and Ely serves to undermine their use of the humanist historian's purpose of recal1ing the past for present emulation, in support of what they present as the "truth" and Henry"s "right"

Another situation in the play where the humanist approach to, and use of, history seems to be undermined is suggested by Fhyllis Fackin in stages of History. The Welsh Captain Fluellen, described by fackin as a "great student of nistory" "a" constant ly refers current events in the play back to those of the ancients, especially "the pristine wars of the Fomans" (TI.ii.79) such as "the wars of Pompey the Great" (IV.i.69). This, of courses was the nature of the humanist historian's practice, and one of the defining characteristics of the fendssance period -.. the "retrieving" of the clasejeal world. It is the scope this practice al lows for tenuous and/or dubious parallels to be drawn between the Cassical and Fenaissance worlds that seems to be the target of the extended andogy that fluellen makes in comparing

apatein; pg 175 
Henry to Alexander the Great. Fackin labels Fluellen's historical connection as a "parodic representation of the humanist historians who ransacked classical texts to find models for modern prineses" 20 with the parody deriving from some of the apparently arbitrary analogous points. Guided by the belief thet "there is figures in all things" (IV vid. B. z), Fluellen sees significance in the fact that "There is a river in Macedons and there is also moreover a river at Mommouth. " and there is salmons in both" (11.25-26." 29). The parody continues with Fluellen drawing a distinction between Alexander's historical friend Cleitus, and Henry's (Prince Hal's) a-historical comrade. Falstaff:

As Alexander billed his friend cleitus: being in his ales and his cups: 50 also Harry Monmouth, being in his right wits and his good judgements. turned away the fat knight with the great-bel1y doublet.

$$
(I V=\text { i. }+42-47)
$$

The effect here, I think, is twowfold "Firstly, Fluellen's incorporation of the fictional Falstaff into his purportedly factual quest for the "figures and comparisons" (1.42) of history serves to undermine further the humanist historian's methodology as the Iines between invention (Falstaff) and reality (cledtus) become blured. Secondly, and in relation to the wider context of the play, Fluellen's analogy acts as a reflection of the ambivalent portrayal of Henry himself in the play as regards his status as either friend or betrayer

\footnotetext{
rafackin, pg 238-239,
} 
of Falstaff and:

by implication, his other acquaintances. At the heart of the matter is the question of how deliberate and calculated Henry (as Frince Hal) was in his friendship with Falstaff and in his subsequent dismissel" "I know thee not: old man" (2 Henry $\left.2 V^{\prime} \quad V . v, 50\right)$. This rejection, actording to Nym, Fistol, and Fluelien, was the cause of Falstaff's death - "The king hath run bad humours on the knight" that's the even of it" (Henry "y Nym, II.i.1.b) - and therefore an act of betraya1. Contrarily, Captain Gower is adamant that Henry "never killed any of his friends" (IV.Vi. 38-39)" Onee more we ere left with the impossibility of gaining in Fobert C. Jones" words. "aceses to Henry's private plans and motives" which would resolve this conundrum but which history neither knows nor supplies.

Each of the examples above -.- Canterbury and Ely's counsel to Henry, and Fluellen's Alexander analogy - seem to point towards a general undermining in the text of humanist nistoriography in favour of a more sophisticated conception of historical thought and conseiousness which differentiates rather than drawe analogies between the present and the past. The humanist historian's belief in the (providential) continuity of history which is the vital premise for their use of history for curent edification or legitimations is in the play taken and used: abused, and manipulated in an environment increasingly defined by Machiavelisan and 
pragnatic: rather than eariy humanist. principles a sophistication inherent in this change comes from the recognition that history is discontinuous rather than continuous: that the past. is past and does not. recur.

In the ease of Canterbury and Elys their advice to Henry to "Look back into your mighty anestors" invoke his warlike spirit" (Canterbury); and "Awake remembranee of these valiant dead, / And with your puissant arm renew their feats" (Ely), while overtly displaying humanist modes of thought: is politically and covertly used to effect the preservation of the Chureh's property privileges. While canterbury and Ely look forward to their future and try to maintain their incomes they tel1 Henry to look back and "renew" history. Aware that history is past and unregainable, possibly through the recognition that their own historical priviledges are about to disappear (history is not continuous if such a change oc(wus), Canterbury and Ely tan use the humanist idea of historical continutey -.. where Henry becomes, in effect, Edwerd II rewincarnated -... to achieve their personal and political ends. In the case of Fluellen. we see the humanist approath to history not manipulated but parodieds as a temuous paraliel between history and the present. is comstructed or contrived. The text seems to be saying here that where parallels are sought they will be found. even

an relation to this point, Fackin, pg 70 , recognises that "Henry appropriates the legitimating emblems of an older world to authorige himself" a also that "the king's recourse to Machiavelian plotting contradicts his representations of his achievements as manifestations of providential purpose " pg 82. 
though they may rest on suen points of comparison as a river containing salmon. of course: Canterbury and Ely use exactly this method in paralleling Henry $\checkmark$ with Edward III though in a far more educated and calculated fashion.

This subversion of the use of historical parallels: then: has the effect of emphasising the idea that the past and present are not the same in either event or character. Both change as time passes: Therefore. any ome moment in or of history is unique and specific, not continuous and consequently a reference point or beacon for the present. $\$$ The situation and circumstances facing Henry are absolutely distinct and completely self-ent losed; not: as Canterbury and Ely almost mischievously reconstruct it in the plays an awakening and renewal of Edward III's situation and wircumstances "3x Historical thought and conseiousness: then" as refracted or transmitted in the text in the form of dramatic historjography, seems to be evolving from humanist ideas of continuity expressed by writers such as Nashe and

owolfgang Iser" in Staging Politics (New York "Columbia University Fress. 1993)" pg 187. \$tates that: "Whoever wishes to interpret the play [Henry b] as evidence that the ideal can be achieved in history must bear in mind the following factors" the ideal is inextricably bound to a single situation" it is unique" it is conditioned by a variety of unrepeatable circumstances, and its effects can in no way enable us to chart the future."

s.Henry is, however, aware of leaving his own name and deeds to and for the use of posterity" aware that he is creating, rather than relivingy what will become history and historiography. This is particularly evident in his speech (IV.iji.40-67) deseribing the glory and renown any viturious survivors of the current battle "upon saint crigpin"s day" "will bask in on its subsequent anniversaries. 
the character Fluelien " to more sophisticated ideas of differentiated discontinuty signalled by the pragmatic and politically aware figures of Canterbury, Ely and: perhaps, Henry.

One further example will suffice to emphasise the distinction and differentiation in Henry $v$ between the past (Edward III) and the present (Henry V) "Nashe's Pierce Penilesses: described how the presentation of dramatic historiography had the effect of making immediately available those historical characters and historical feats displayed for the instruction and edification of the play-going audience. Nashe's argument, even his images, would seem to be refuted "however, in a speech by Exeter, early in Henry $W_{3}$ where he presents the French king with an account of Henry's Elam to the French throne:

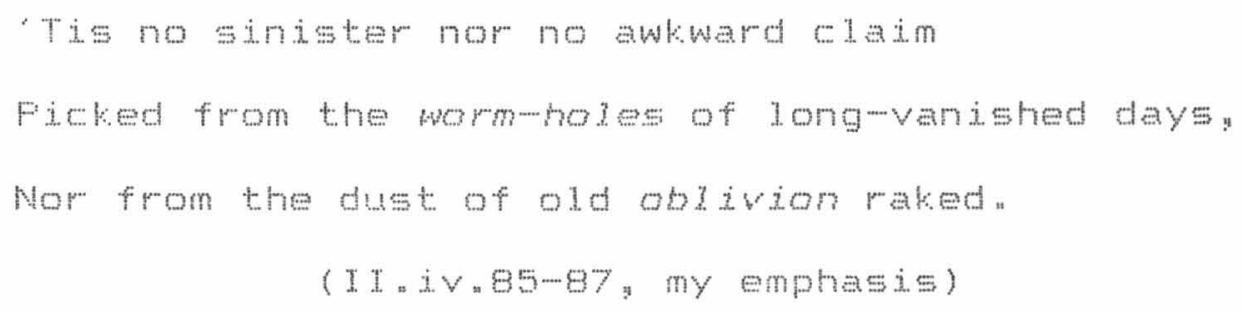

Using terms that echo those of Nashe: this passage seems to implicitiy question the connection Nashe establishes, through historical drama, betwen the past and present. Exeter's statement that Henry"s elaim is neither" "sinister" nor "awhward" may not sit well with the earlier" scene of Canterbury and Ely's plotting and the claim they contrive for

wae pp $114-115$ 
Henry out of the "long-vanished days" of French history. Aware of the contingency of their situation regarding the "bill" they can use history under the guise of humanist emulation of past heroes to maintain their currenty and Future" ineome " History, then " becomes a vehicle for distraction rather than a guide or model for the present.

So far. this discussion of Henry has focused on the stage action of the play and the way it seems to undermine Fenaissance humanist historiography through characterisation of Such men as Fluellen and Canterbury and Ely outside of this action, yet a vital contributor to the history presented (and represented). is the chorus which opens and closes the play dinks the action from Act to Act. and which "embraces the role of the historian "wa It is in the chorus that we can see evidence of the text selfwonsciously and selfin reflexively coming to terme with the process of nistorical representetion a and the melated problems of historical or historiographical "truth" "As such, it is possible to see the Chorus of Henry $\psi \mathrm{as}$ a realisation of the ideas and issuss first broached in the Countess of Auvergne - Lord Talbot episode of I Hemry wros where Talbot clamed that that which the Countess sees bears 1itte resemblanee to the true nature and proportion of things ... "I tell you, madam, were the whole

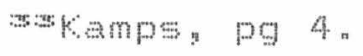

34kamps, pg 19\%, identifies shakespeare's Henry as one of the Tudor drama"s "instances of highly complex and selfconscious treatments of the character of historiographical representation "

ssee Chapter 1, pp $27-3$.
} 
frame here, / It is of such a spacious lofty pitch / Your root were not sufficient to contain t" ( 1 Henry Wy II. i.j.5.55) - the chorus's "Frologue" to Henry w" in similar fashion, emphasises the inability of the stage to show the true sope of events:

can this cockpt hold

The vasty fields of France? or may we cram

Within this wooden o the very casques

That did affright the air at Agincourt?

$$
\text { (Frologue, } 11-14 \text { ) }
$$

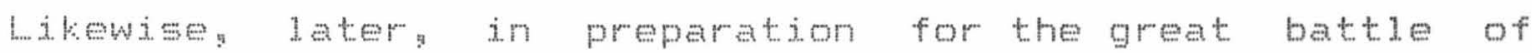
Agincourt, the Chorus apologises for the mockery they make of the historical truth

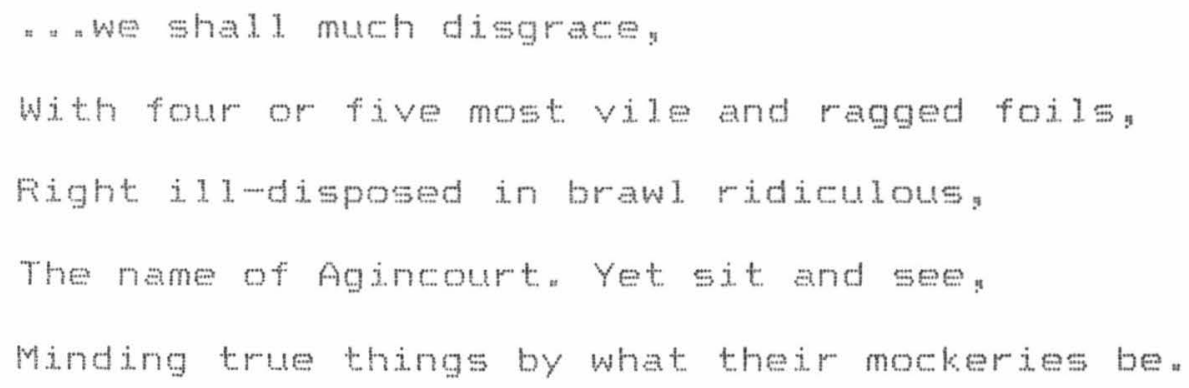

The historical truth; then, like Talbot's "substance" cannot be fully possessed or captured on stage: it is entirely elusive. Once a moment, comprised of character and event, has passed into the realm of history it can only be retrieved as "morkeries" or "shadow", that is, as something that resembles or stands for the truth. Henry y in constantly setting in oppostion the historical action, heralded or introduced by the Chorus, that comprises the body of the play 
with the historical reality or "truth" that the chorus itself is seeting to represent: has the effect of

directing our attention to the abyss at the center of the historiographic project: the impossibility of mecovering the pest or of getting behind the nistoriographic text whether that text be a written record or a dramatic representation) to discover the always postulated and never graspable fiction called nistorical truth.

The historical thought and consciousness in Henry $y$ can therefore be seen as a development and complication of the seminal ideas and issues contained in the Herry yt sequence. The character York's use of history for personal advancement is here enlarged to the use of history by Canterbury and E1y for personal and professional preservation, within a context which renders Henry sesponses and actions opaque. Likewise the interaction in Henry between the chorus and the stage action" creating an "abyss" where "truth" is constantly receding develope the earlier debate between the countess of Auvergne and Lord Talbot on the "truth" of "report" and points to the ineluctable presenee in any historiographical work of "shadow" rather than "substance"

\footnotetext{
mefackin. pg 6\%. kamps. pg a7. similarly finds a "deep ideological rift" between "the chorus" version of history" " [and] the dramatic-nistorical tale that acounts for the rest of the play" As an example he cites the opening of the play where we see "not proud horses and heroically decked-wout kings [as suggested in the prologue] but two conniving churehmen who are instantly implicated in an opportunietie political deal with Henry."
} 


\section{Conclusion}

Those of Shakespeare's English history plays discussed here - Henry WT Parta 1, 2, \& 3, Richard 3 and Henry $v$ - do seem to evince, in terms of late-sixteenth century historical thought and consciousness: the transitional and progressive quality ascribed to them by Holderness, Rackin, and, to a lesser extent, Kamps. As sumn, the plays, in Holderness's words, intervene in and contribute to the wider historiographic effort to "reconstruct the past and discover the methods and principles of thet reconstruction."

We began with Shakespeare's Henry VI sequence and its dramatic presentation of the historiography of the Chronicles. Not only does this dramatisation result in the apparent resurrection of characters and events that in Nashe's words, "have line long buried in rustie brasse and worme-eaten bookes", but it also subjects those characters and events recorded in the Chronicles firstly to the dramatic and narrative requirements of the stage, and secondly to reconstruction and re-organisation of the dramatist, Shakespeare" as "historian" "This new dramatic presentation of old "bookes" required above all else a linear narrative of (temporal) cause and effect, a form of narrative which was not always supplied by the Chronicles. It therefore rested with the dramatist as "historian" to examine and explore all the evidence and information available, and then to select or decide what, in his opinion, probably happened. The importance of this step with regard to historical thought and 
consciousness was that it required the historiographer to use historical judgement and interpretation in his reconstruction, and thus become actively involved in his task. This professional involvement was contrary to the melatively pessive mepetition, signalled in the processes of adaptation and aceretion, of the antecedent chroniclers. 1

Having assumed this control over history, it became necessary to "discover the methods and principles" on which the subsequent reconstrution of history could be based. Shakespeare seems to have been aided in this by Sir Thomas More: Iegally influeneed History of King Richard III, Shakespeare's main souree for his Fichard IY. Legal "methods and principles" were equally applicable to the historian's task. As the lawyer struggled with the difficulties of oral testimony, contradictory accounts of events; and the task of geeting and interpreting evidence to ascertain the "truth" the historian faced the problems assotated with using oral report as a nistorical soures " and the problematic discrepaney that exists between the sought after "inner" invisible truth" and the "external appearances" from which that "truth" must. by lawyer and historian alikeg be extracted.

\footnotetext{
Kamps, pg 199, however, cites a recent development on this view of the Chroniclers in a book by Annabel Fatterson Feading Holinshed s Chronickes (Chicago and London" University of Chicago Fress, 1994) - which reconsiders "the familiar view of Holinghed as a 'baggy and undisciplined" tome" and finds "much greater political and methodological diversity than hitherto thought possible."
} 
It is the awareness of this discrepancy: and the consequent realisation of the evasive nature of the "truth", thet leads to what Fackin terms "the abys at the center of the historiographir project" "In shakespeare's Henry y. the "abyss" is especially prominent as the action of the play" itself laden with ambivalence and ambiguity as regards its "hero" is introduced and offset by the commentary of the Chorus:

The dramatic and historiographic qualities of Henry $\quad$ and the history play it is here paired with - the anonymous Edward IIY - have the effect of highlighting two major points of transition and progression affecting contemporary historiography and the history play genre as a wholea firstiy the increasing distinction between nistory and poetry as evidenced in the Edward III - Countess of Salisbury episode of Edward III secondly the change in the methodology of nistory (from humenist or "public" to Machiavellian or "private") and consequent change in the perception of history (from continuous to discontinuous). This second change is shown as we see Edward IIT'3 concluding dictate of how the history there presented should be used in "hereafter ages" explicitiy usurped and corrupted at the opening of Henry $y$

In conelusion" then "we can state that shakespeare's English history plays are a form of dramatic historiography that is in its latewsixteenth century context. transitional and progressive in terms of historical thought and consciousness "The plays increasingly show a (self-reflexive) 
awareness of the impossibility of knowing (and thus presenting) the "truth" while also, through their fusion of dramatic poetry and history. paradoxically contributing to the emerging distinetion between poetry and history" This distinetion wil eventually lead to the autonomy of history as a discipline which, in combination with the drama's increased self-reflexivity, will result in the overall demise of the history play genre. 


\section{Bibliography}

Axton, Marie. The Queen's Two Bodies. London: Foyal Historical Society, 1977.

Baker: Hersche1. The Race of Time: Three Lectures on Renaissance Historiography " Toronto" University of Toronto Press; 1967.

Bellamy, ${ }^{3}, \mathrm{~s}$. The Law of Treason in England in the Later Middle Ages. Cambridge: Cambridge University Press, 1970 .

Bellamy, John. The Tudor kaw of Treason - An Introduction. London: Foutledge \& Kegan Faul, 1979.

Benson. Larry D." gen. ed. The Riverside Chacer. Oxford: Dxford University Fress; 1992 .

Broughton, Bradford " Dictionary of Medieval knighthood and Chivalry " Westport, Connecticut: Greenwood Fress: 1986.

Bullough, Geofrey, ed. Narrative and Dramatic Sources of Shakespeares 6 vols. London: Routledge and Kegan Faul, $1960, \mathrm{VOI}$. III.

Burke, Peter. "The Fenajsance Sense of the Past. London" Edward Arnold (Fublishers) Ltd, 196\%.

Champion, Larry S. Pergpective in Shakespeare's English Histories. Athens: University of Georgia Press. 1980.

Collingwood" F.G. The rdea of History. Oxford" Oxford University Press: 1946.

Douglas, Louise; Alan Roberts and Futh Thompson " Oral History - A Handbook. Sydney: Allen a Unwin. 1988.

Elyot, Eir Thomas. The Eook named The Governor (1531). Ed. S.E. Lehmberg. London: Everyman's Library. J.M. Dent \& Bons Ltd, 1966.

Figgis, John Neville. The Divine Pight of Kings "Cambridge" Cambridge University Press. 1914. 
Fusener, F. Smith. Tudor History and the Historians. New York: Basic Books; 1970 .

Harris" G.L" ed. Henry b" The practice of Kingship. Oxford: Oxford University Fress. 1985.

Heywood, Thomas. An Apology for Actors (1612). New York: Johnson Reprint Corporation, 1972.

Holderness" Graham. Shakespeare's History" Dublin" Gill and Macmillan L.t.t. 1985.

Holderness: Graham. Shakespeare Fecycled" The Making or Historical Drama. Hertfordshirea Harvester wheatsheat. 1992.

Holdernes: Graham, Nick Fotter and John Turner. Shakespere: The Play of History. Towa city" University of Iowa Fress, 1988.

Holnohed"s Chronicle as used in Shakespeare's Plays Ed. Allardyce Nicoll and Josephine Nicoll. London: Everyman's Library, J.M. Dent \& Sons, 1927.

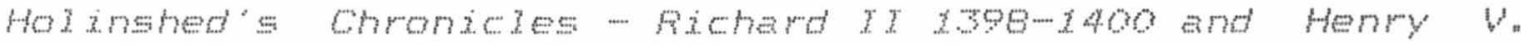
Ed. Fis. Wallace and Alma Hansen. Oxforda Clarendon Pres: 1917 .

Iser" Wolfgang. Staging politics - The tasting Tmpact of Shakespeare's Histories. Trans. David Henry wilson. New York: Columbia University Fress. 1993 "

Jones, Robert $\mathrm{E}$. These Valiant Dead -- Penewing the past in Shakespeare's Histories. Iowa city" university of Iowa Press, 1991.

kamps. Tvo" Historiography and ldeology in Stuart Drama. Cambridge: Cambridge University Fress. 1996.

Kantororwicz: Ernst H. The Kings Two Bodies" Princeton: Princeton University Fress. 1957.

Kastan. David Scott. "Froud Majesty Made a Subject" Shakespeare and the spectacle of Rule." Shakespeare Quertery, $37(1986), 459-475$ 
Kenda1. Faul Murray, ed. Fichard Trt - The Great Debate. New York: W.W. Norton \& Company 1992.

Lapides, Fred: ed. The Raigne of King Edward the Third. New York: Garland Fublishing, Inc." 1980.

Mokerrow, Fonald B., ed. The Works of Thomas Nashe, 5 vols. London: Sidgwick \& Jackson, Ltd, 1904, vol. I.

Maus, Katherine Eisaman. "Froof and Consequences: Inwardness and Its Exposure in the English Fenaissance:" Representations, 34 (Spring 1991), 29-52.

Metz: Harold 0. Sources of Four plays Ascribed to shakepeare. Columbian Unjversity of Missouri Fress. $198 \%$

Stanyhurst, Fichard. Holinshed's Trish Chronicle (1577 ed.). Ed. Liam Miller and Ejleen Power" " Dolmen Editions. North America: Humanities Frese Ine: "1979"

Pearlman, E, William shakespearez The History Plays. New York: Twayne Fublishers, 1992.

Fugliatti. Faola. Shakespeare the Historian. London" Macmillan Fress Lte.t. 1996.

Rackin: Fhyllis. Stages or History - Shakespeare's English Chronicles. New York" Cormell University Fress" 1990.

Fibner, Irving. The English History play in the Age of Shakespeare. London: Methuen \& Cos 1965.

Fossiter; A.F", ed. Moodstocks A Moral History London" Chetto and windus: 1946.

Saction Feter. Shekespeare's English kings "oxforda oxford University Fress. 1977 .

Shakespeare: William. The second Part of king Henry the Fourth Ed" F.H. Davison. London: Fenguin Books Ltd. $1977^{\prime \prime}$ 
Shakespere, wiliam. The First part of king Henry Wh. Ed. Michael Hattaway. Cambridgea Cambridge University Fress. 1990.

Shakespeare" William. The second Part of king Henry WI. Ed. Micael Hattaway. Cambridge: Cambridge University Fres: 1991.

Shakespeare, William. King fichard the Third" Ed. E.A.J. Honigmann " London" Fenguin Books Lted, 1986.

Shakespeare, William. Henry " "Ed "A. Fumphreys. London" Penguin Books Lted, 1988.

Shakespeare" William. The First part or king Henry the Sixth. Ed. Norman Sanders. London" Penguin Books Ltd, 1981.

Shakespeare. William. The Second part of king Henry the Sixth. Ed. Noman Sanders. London: Penguin Books Lte. 1.981.

Shakespeare: William. The Third Part or king Henry the Sixth. Ed. Nornan Sanders. London" Fenguin Books Ltd, 1981.

Sidney: Sir Philip. An Apology for Poetry. Ed. Geoffrey Shepherd. Manchester" Manchester University Fress. 1980.

Thayer, C. o. Shakesperean Poilics a Government and wisgovernment in the great Histories. ohio: onio University Fress, $198 \%$

Tillyard, E.M.W. Shakespeare's History Plays London: Chatto and windus 1961 .

Vansina, Jan. Grel Tradition as History Hondon" James Curry Lted, 1985.

Watts Jonn. Henry Wh and the Politics of Kingship. Cambridge: Cambridge University Press, 1996.

Weir, Alison. The Princes in the Tower. London: The Bodley Head, 1992. 